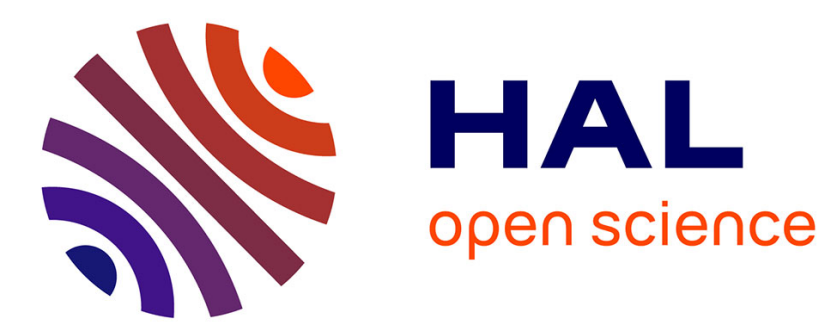

\title{
Deep sea rock record exhumed on oceanic volcanic islands: the Cretaceous sediments of Maio, Cape Verde
}

Max Casson, Luc Bulot, Jason Jeremiah, Jonathan Redfern

\section{To cite this version:}

Max Casson, Luc Bulot, Jason Jeremiah, Jonathan Redfern. Deep sea rock record exhumed on oceanic volcanic islands: the Cretaceous sediments of Maio, Cape Verde. Gondwana Research, 2020, 81, pp.252-264. 10.1016/j.gr.2019.11.007 . hal-03016464

\section{HAL Id: hal-03016464 \\ https://hal.science/hal-03016464}

Submitted on 23 Feb 2021

HAL is a multi-disciplinary open access archive for the deposit and dissemination of scientific research documents, whether they are published or not. The documents may come from teaching and research institutions in France or abroad, or from public or private research centers.
L'archive ouverte pluridisciplinaire HAL, est destinée au dépôt et à la diffusion de documents scientifiques de niveau recherche, publiés ou non, émanant des établissements d'enseignement et de recherche français ou étrangers, des laboratoires publics ou privés. 


\title{
DEEP SEA ROCK RECORD EXHUMED ON OCEANIC VOLCANIC ISLANDS: THE CRETACEOUS SEDIMENTS OF MAIO, CAPE VERDE
}

Max Casson ${ }^{1}$, Luc G. Bulot ${ }^{2,1}$, Jason Jeremiah ${ }^{3}$, Jonathan Redfern ${ }^{1}$

${ }^{1}$ North Africa Research Group, University of Manchester, Oxford Road, M13 9PL

${ }^{2}$ Aix-Marseille Université, CNRS, IRD, Collège de France, INRA, Cerege, Site Saint-Charles, Case 67, 3, Place Victor Hugo, 13331, Marseille Cedex 3, France

${ }^{3}$ Golden Spike Geosolutions Ltd., 20 Ten Acres Crescent, Stevenage, Hertfordshire, SG2 9US

\begin{abstract}
Revising the deep water stratigraphy exposed on Maio offers a key section recording the sedimentary evolution in the distal domain of the Central Atlantic and the related North West African Atlantic margin (NWAAM). The oceanic volcanic island is one of nine islands in the Cape Verde archipelago, and is unique to the Central Atlantic due to the exposures of ophiolites and the overlying Mesozoic deep water sediments uplifted during the Cenozoic. This provides the opportunity to assess at outcrop, the exhumed sediments, stratigraphy and paleo-environments of the early Central Atlantic and contribute towards the knowledge of passive margin evolution along the NWAAM, part of the largest continental remnant of Gondwana.
\end{abstract}

Combined with the previous recording of calpionellids, the first collection of lower Valanginian ammonites from the lowest sedimentary succession provides conclusive evidence that Jurassic sediments are not present on Maio. Bed-by-bed sampling and ensuing micro-palaeontological analysis of these 71 samples, together with a re-interpretation of Stahlecker's remaining historical palaeontological collection providing a comprehensive dataset to build a high-resolution stratigraphic framework for the Mesozoic sediments. This reveals pelagic deepwater limestones of the Morro Fm. were deposited until the upper Barremian. A major lithological change from carbonate- to siliciclasticdominated facies, corresponding to the Morro-Carquiejo Fm. boundary is recognised as a regional hiatus spanning part of the Aptian identified across the Central Atlantic. The overlying Albian and younger Carquiejo Fm. is seen as an equivalent to the Albian-Cenomanian black shales of DSDP Leg 41, yet organic content is absent due to degradation. Future studies can build on this multi-disciplinary investigation and rely on the revision of the stratigraphy of Maio. 
Key Words: distal domain; stratigraphy; Central Atlantic; Maio; exhumed oceanic volcanic islands

\section{Introduction}

Exhumed sediments on oceanic volcanic islands offer the opportunity to examine at outcrop deep sea sediments deposited in passive margin basins that are otherwise only penetrated by the drill bit and/or imaged using seismic reflection techniques. The fortuitous uplift of these sediments surrounding the igneous complex allow a comprehensive analysis of deep-water stratigraphy; allowing a stratigraphic framework to be developed for the distal domain and post-rift sedimentology to be fully examined using conventional fieldwork and ensuing laboratory analysis.

The study of the island of Maio in the Cape Verde archipelago provides an opportunity to assess the paleo-environmental evolution of the early Central Atlantic and contribute towards the knowledge of the evolution of the NWAAM. This margin is part of the largest remnant of early Gondwana, the African continent. New findings are integrated with results from the Deep Sea Drilling Project (DSDP) and comparisons made with Mesozoic outcrops of Cuba and more generally with the Maiolica facies across the Central Atlantic to correlate interpretations regionally.

This multi-disciplinary analysis refines the stratigraphic scheme developed by geologists, palaeontologists and stratigraphers since the early 20th century (see Fourcade et al., 1990 with references). We also document the first collection of ammonites from the lowest part of the sedimentary succession, with bed-by-bed sampling and high-resolution micro-palaeontological analysis, combined with a re-interpretation of the remainder of the palaeontological collection of Stahlecker (1935). This provides a comprehensive dataset that allows definition of a high-resolution stratigraphic framework to address uncertainties surrounding the dating of the Mesozoic stratigraphy of Maio. 


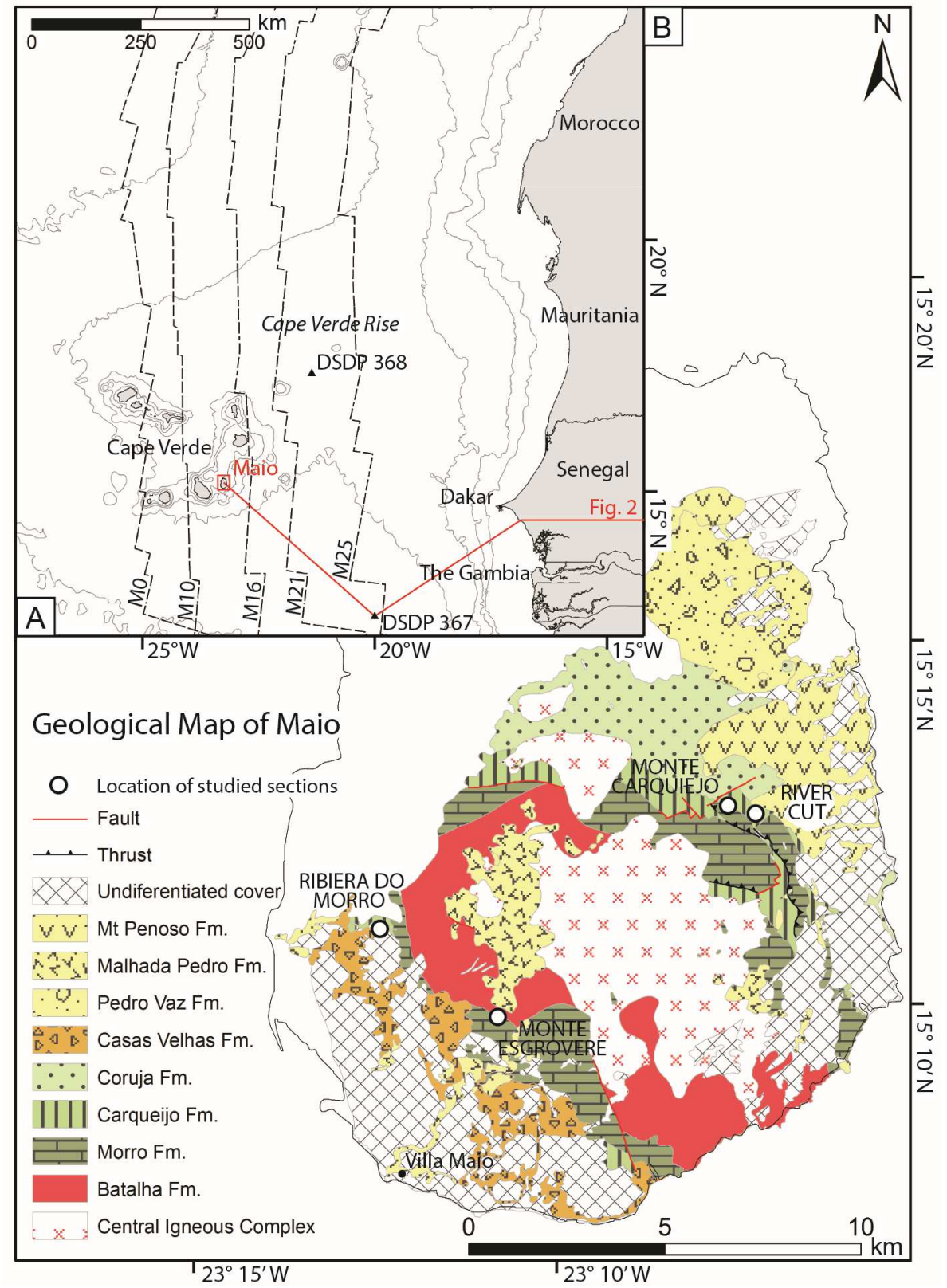

Fig. 1 (A) - Location map of the Cape Verde archipelago with magnetic anomalies (M0 125 Ma, Barremian-Aptian boundary; M10 130 Ma; M16 145 Ma; M21 148 Ma; M25 154 Ma; Seton et al., 2014), DSDP boreholes and location of Fig. 2 displayed. Bathymetric contours every 1000 m. (B) Geological map of Maio after Stillman et al. (1982), with the locations of four studied sections presented in this paper.

The Cape Verde archipelago is located in the Atlantic Ocean, ca. 500 km west of Dakar, Senegal and ca. 2000 km east of the present-day Mid-Atlantic Ridge (Fig. 1A). It encompasses 9 major active and inactive volcanic islands. The island of Maio is part of the eastern N-S orientated chain, interpreted to be older (10-20 Ma) than the western chain (<8 Ma; Holm et al., 2008). The islands rise $2-4 \mathrm{~km}$ above the surrounding seafloor (Hayes \& Rabinowitz, 1975), where magnetic anomalies have been identified 
suggesting mid-plate emplacement on oceanic lithosphere between M11 ( 136 Ma) and M16 ( 145 Ma; Fig. 1A; Gradstein et al., 2012). The archipelago formed in the southwestern corner of the Cape Verde Rise, one of the largest bathymetric swells in the world, elevated ca. $2.2 \mathrm{~km}$ above the expected depth of the seafloor (Pim et al., 2008). It is generally accepted that the islands and swell formed above a deep mantle plume with associated hot spot activity (Crough, 1978) and postulated dynamic uplift (Pim et al., 2008). Flexure of the surrounding plate by Early Miocene volcanic loading created a concentric flexural moat with $2 \mathrm{~km}$ of stratigraphic infill (Ali et al., 2003).

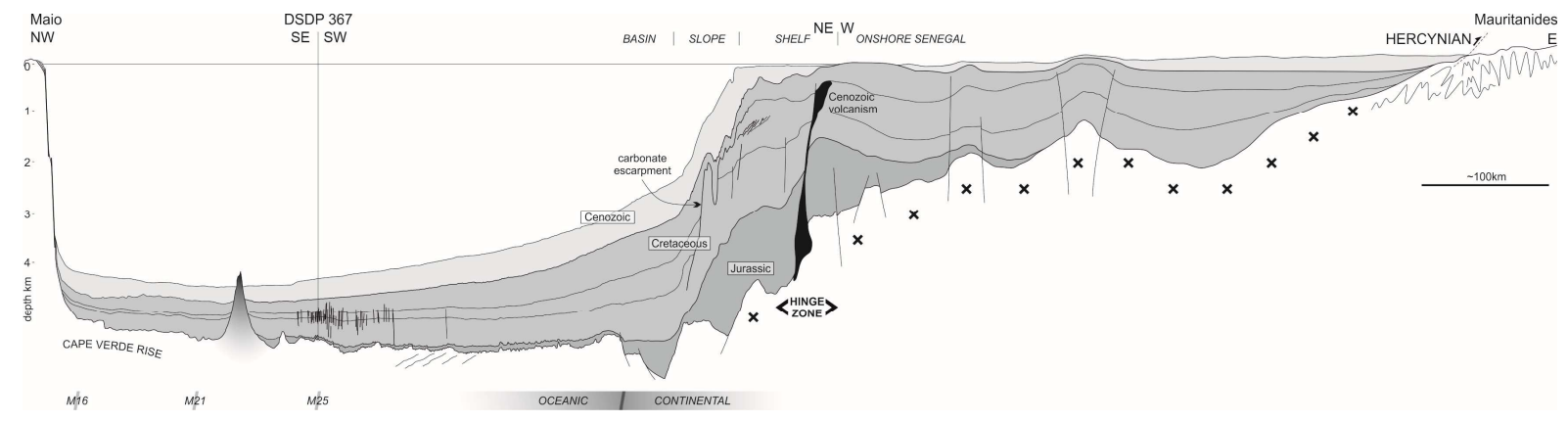

Fig. 2- Schematic cross-section through the NW African Atlantic passive margin highlighting the main stratigraphic packages and architecture of the basin. Approximate locations of DSDP 367 and magnetic anomalies (Seton et al., 2014) shown. Location of section detailed in Fig. 1A.

Maio is unique among the Cape Verde archipelago as it hosts a complete sedimentary sequence resting on ocean floor extending to the volcaniclastic sediments that record emergence of the oceanic island (Fig. 1; Fig. 2). These outcrops offer the only opportunity to study exposed deepwater Cretaceous successions at outcrop in the Mauritania-Senegal-Guinea Bissau-Conarky (MSGBC) Basin. The stratigraphy was summarised by Fourcade et al. (1990) and the chronostratigraphic events from previous workers are presented in Fig. 3. Exposed at the core of Maio is the Central Igneous Complex (CIC), an unroofed alkaline plutonic body intensely intruded by swarms of sills and dikes with mafic to intermediate composition (Serralheiro, 1968). The Mesozoic stratigraphy is exposed in a ring of outcrops, radially dipping away from the $\mathrm{CIC}$ (Fig. 1B), consisting of 4 formations: the Batalha Formation - normal-type mid-ocean ridge tholeiitic pillow basalts (de Paepe et al., 1974); the Morro Formation homogeneous thick bedded fossiliferous pelagic limestones becoming thin bedded with interbedded marls upwards (informally termed the 'upper transitional unit' by Robertson, 1984), with a basal ferruginous facies; the Carquiejo Formation - heterogeneous unit of shales, siltstones and limestones; and the Coruja Formation - tuffs, sandstones and conglomerates (Stillman et al., 1982; Robertson, 1984). The Mesozoic stratigraphy is unconformably overlain by Tertiary and Quaternary formations associated with Maio's emergence. 


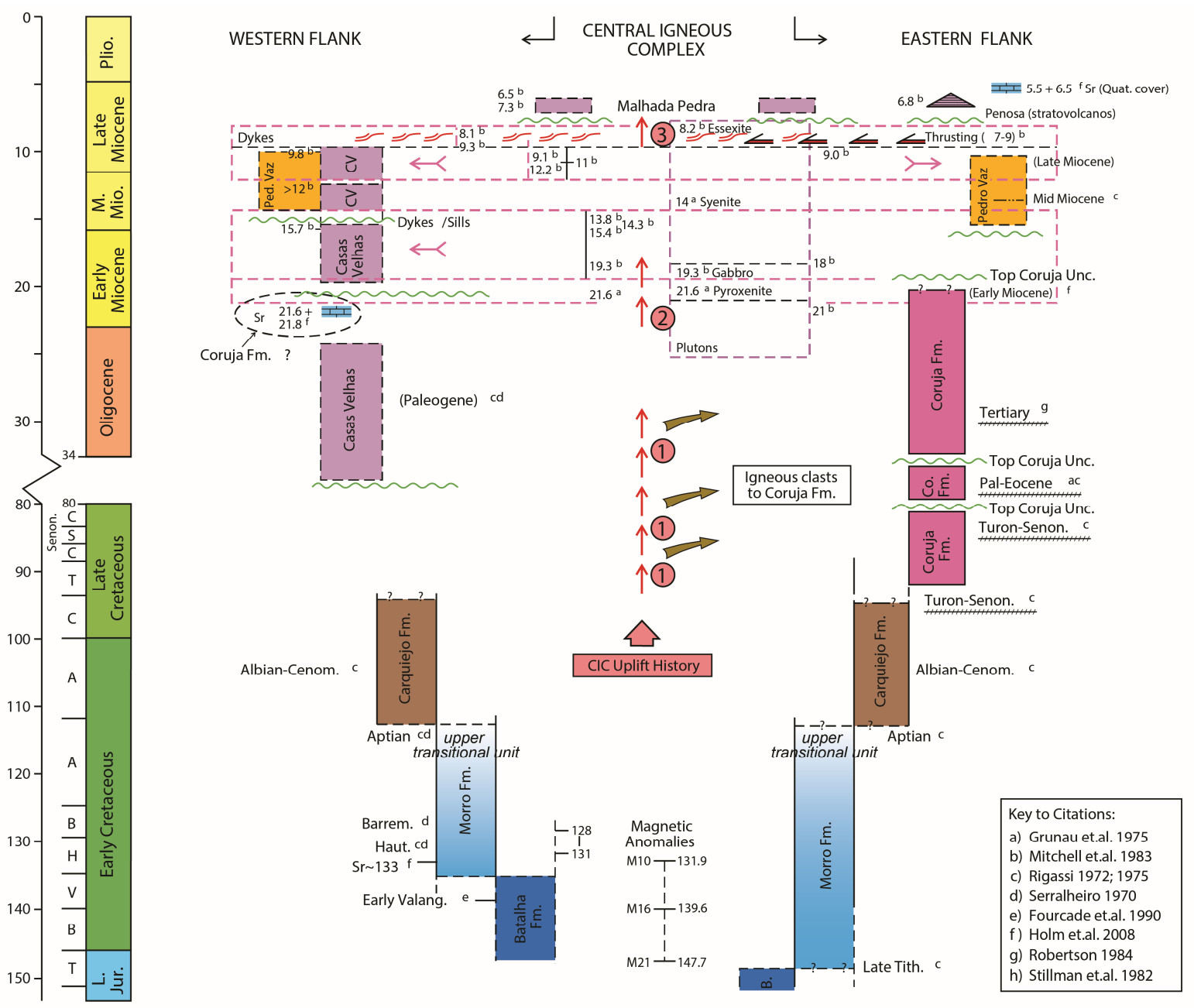

Fig. 3 - Chronostratigraphic summary chart for the geological evolution of Maio. Inset - references. Kindly provided by Steve Lawrence (pers. comms. 2018).

\section{Methods}

A multi-disciplinary approach has been adopted to the analysis of Maio sediments to build on existing studies and utilise previously captured data. New ammonoid findings and key calcareous nannofossil species are fully illustrated for future reference.

\section{Sedimentology}

Detailed sedimentary logging was performed during one field season and samples collected for subsequent petrographical investigation. Five black shale samples were selected for organic geochemical analysis using a Shimadzu TOC-V CPN and Solid Sample Module (SSM), calibrated to sodium carbonate and glucose to measure inorganic and total carbon respectively. None of the samples yielded any organic carbon content. 


\section{Biostratigraphy}

\section{Calcareous nannofossil biostratigraphy}

71 samples from Maio were analysed with standard techniques described by Bown (1998), and the picking brush method of Jeremiah (1996). Samples were analysed semi-quantitatively, with the first 30 fields of view counted and the remaining slide scanned for rare specimens. Sampling focused on the upper transitional unit and overlying Carquiejo Fm. where marls were abundant, however recovery was generally poor. Key specimens from the section are illustrated with the associated log.

\section{Macro-fossil biostratigraphy}

Due to intensive quarrying activities, the collection of new macro-fossils was challenging. However, a new assemblage of limonitic ammonites was made at Monte Esgrovere (Fig. 1B), belemnite specimens recovered from Monte Carquiejo (Fig. 1B) and Aptychi discovered throughout the sections. To complement the analysis of new material, the authors accessed the macro-fossil collection of Stahlecker hosted in the Palaeontological Museum of the University of Tübingen, where all remaining specimens were documented and photographed.

\section{Foraminiferal biostratigraphy}

10 samples were chosen with relatively abundant calcareous nannofossil content and prepared using the standard methodology described by Armstrong and Brasier (2005). All samples except one, RC-6, yielded no visible microfossils, likely due to the altered nature of the lithology.

\section{Calpionellid biostratigraphy}

Following the report of calpionellids by Fourcade et al. (1990), four samples from Monte Esgrovere were cut for thin sections in two planes. Unfortunately, there were no notable calpionellid occurrences.

\section{Results}

Five sections were selected for detailed bed-by-bed logging and sampling after thorough reconnaissance following the geological map of Stillman et al. (1982). Since the earlier work of Stahlecker (1935) and Serralheiro (1975; see their Fig. 4) the nature of the outcrops have been affected by local quarrying. Unpublished field photographs in the collection of Stahlecker Tubingen Museum, and photographs published by Serralheiro (1975) show abundant surface exposure at Ribeira do Morro, 
but most of this has now been removed and quarried (see supplementary data Fig. S1). Although more complex, access to the sections is still possible.

Data was attained from both flanks of the island to provide spatial coverage, with a maximum distance between sections of $c a .10 \mathrm{~km}$ East-West. The definition of the Morro-Carquiejo Fm. boundary by Stillman et al. (1982) was recognised and followed; this contact is commonly intruded by younger intrusives exploiting the rheological weakness between the different lithologies. On the eastern flank, the authors are in agreement with Stillman et al. (1982) that the stratigraphy has been thrusted. 
Ribeira do Morro Section (Sample prefix: RDM) 


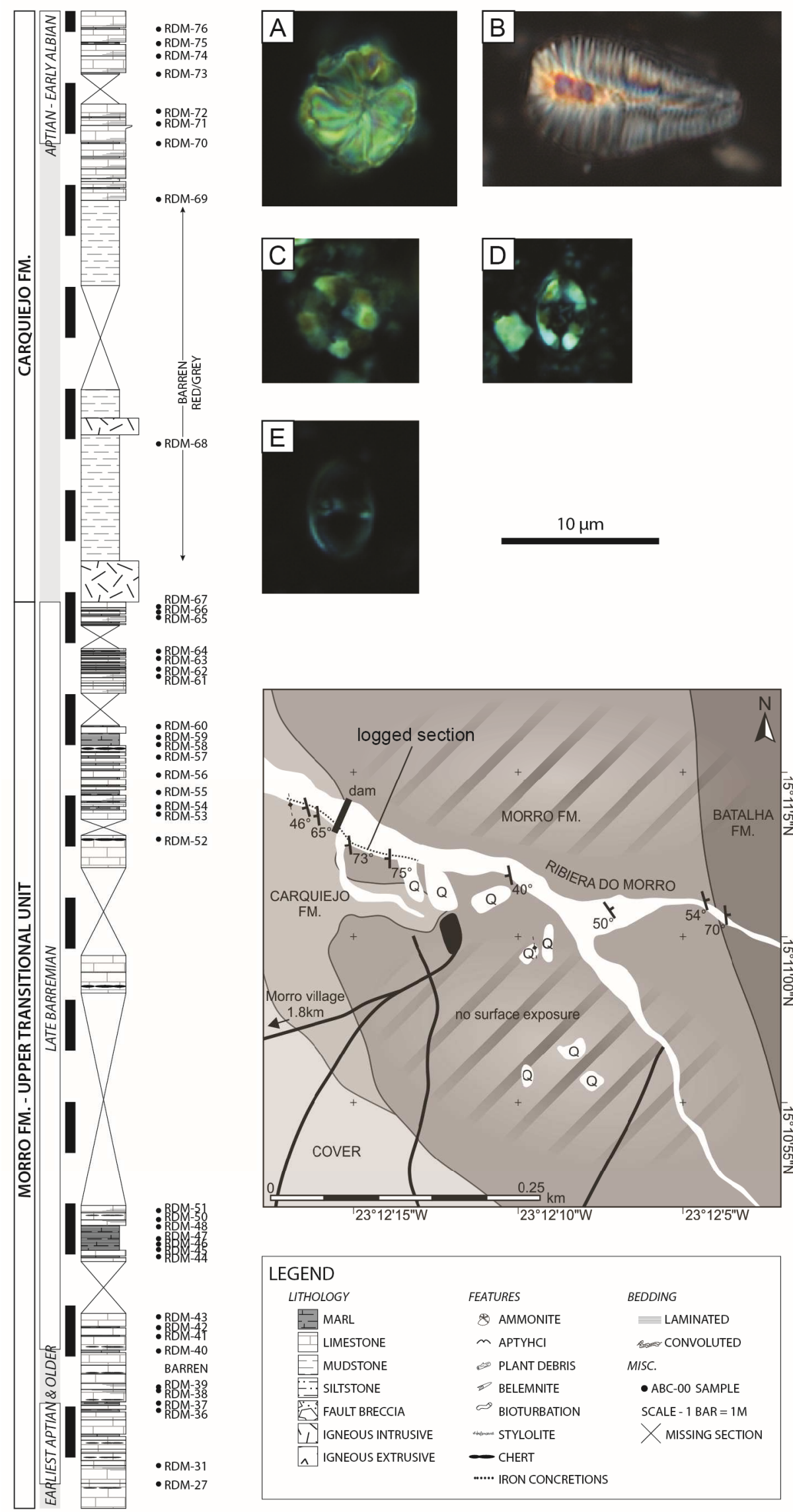

RIBEIRA DO MORRO

Lat: $15^{\circ} 11^{\prime \prime} 3^{\prime \prime} \mathrm{N}$; Long: $23^{\circ} 12^{\prime} 15^{\prime \prime} \mathrm{W}$ 
Fig. 4 - Detailed sedimentary log with the majority of igneous intrusions removed from Ribeira do Morro, see location in Fig. 1B. Samples taken for the calcareous nannofossil biostratigraphy are annotated, five specimens are illustrated: (A) A. youngii, (B) N. steinmannii, (C) C. rothii, (D) E. turriseiffelli, (E) Z. scutula, and the distribution charts are provided in the supplementary data (Table S1). Inset - a sketch geological map highlighting where the section was logged along in the river bank exposures and in subsurface quarries, the lack of surface exposure due to quarrying activities (see supplementary data Fig. S1) and structural data recorded in the field.

The most complete succession, previously documented, is now a more complex exposure of isolated small quarries and small outcrops along the ephemeral Morro River (Fig. 4). It was possible to log the exposures in the river bank as shown in Fig. 4 (map inset) and construct a composite log. This can be correlated with the graphical reconstruction of Stahlecker's log of the full Ribeira do Morro sequence, shown in Fig. 5, with the palaeontological horizons annotated. The stratigraphic location of our composite log (Fig. 4) is displayed on the complete log (Fig. 5). These were well documented and the specimens in the Tübingen collection viewed and re-described as part of this study.

\section{Lithofacies}

\section{Batalha Formation}

Basaltic Pillow Lava - The base of the section exposes coarse-fine grained, dark green-grey basaltic pillows with a maximum diameter of $60 \mathrm{~cm}$, surrounded by thermally altered meta-sediments. These crop out in isolated exposures at the head of the Morro River, $2.2 \mathrm{~km}$ ENE of Morro village. Traversing west (Lat.: $15.18357^{\circ}$, Long: $-23.20195^{\circ}$ ), the Mesozoic sequence can be followed downstream. Faulting is inferred from deformation of bedding and dips, and intrusions are common. The contact between the Batalha and Morro Fm. is placed in a heavily deformed zone with fault breccias and dikes.

\section{Morro Formation}

Massive to bedded limestone facies - The lowermost Morro Fm., above this ill-defined contact, is composed of dark grey-black, thickly-bedded (av. $30 \mathrm{~cm}$ ) to massive cyclical limestone with common stylolites and calcite veining. The limestones contain vitreous black chert horizons and nodules and show minor parallel laminations. Partings are undulating and marls absent. Sample RDM-12 is a typical Morro Fm. limestone, which in thin section records a micritic matrix with a wackestone texture, also containing recrystallized radiolarian and pyrite (see supplementary data Fig. S2). A stratigraphic gap of estimated $100 \mathrm{~m}$ thickness exists between this exposure in the stream bed and the first subsurface quarry, this interval is also cut by small faults, which can be observed offsetting the stratigraphy between exposures, and folded in places (see supplementary data Fig. S3A). Within the first quarry, the almost vertical Morro limestones revealed common apytchi on certain bedding planes. Chert content 
decreases and the limestone is generally a lighter grey colour and up-section the beds become thinner. Sample RDM-30 contains abundant pyrite within the nodular texture of the micritic limestone. The limestones have undergone the early stages of the pressure-solution processes, with stylolites beginning to form (see supplementary data Fig. S2).

Slow accumulation of the massive to bedded limestone facies occurred in a deep-water setting by pelagic deposition, above the calcite compensation depth (CCD). The repetitive nature of the beds with consistent lateral continuity indicates steady cyclical sedimentation across the sea floor with minor current activity producing undulating partings (Stillman et al., 1982). Our analysis of thin sections has failed to find any quartz within this facies; this is in agreement with Robertson's (1984) interpretation that this part of the basin was isolated from terrigenous sediment during deposition of this facies.

\section{Upper Transitional Unit}

Flaggy limestone facies - Exposure of flaggy limestone beds are observed in the river bank upstream and downstream of a small dam (Lat.: $15.18429^{\circ}$, Long: $\left.-23.20429^{\circ}\right)$. The flaggy limestone beds are generally thinner bedded (av. $10 \mathrm{~cm}$ ), increasingly laminated and less silicified. Interbedded bituminous, fissile, calcareous mudstones were sampled for nannofossil content (RDM-36 to 67, Fig. 4). An ichnofacies is recorded in these sediments at the MC section (see Section 4.3.1). Horizons of mm-scale iron concretions occur in the flaggy limestones. A fairly large number of aptychi, fish remains and ammonites were collected from this part of the succession, some of which were published by Stahlecker (1935) and revised below.

The contrasting facies of the upper transitional unit to the main Morro Fm. was deposited by distal turbidites and the thinner bedded nature of the flaggy limestones indicates less continuous pelagic sedimentation between events. The increasing clay content suggests terrigenous material reached the deep basin. These depositional conditions favoured the preservation of calcareous nannofossils, trace fossils and ammonites.

\section{Carquiejo Formation}

Non-calcareous silicified mudstone facies - The change from calcareous to non-calcareous dominated sedimentation and the absence of competent limestone beds is taken as the Morro-Carquiejo Fm. boundary. A regional $70 \mathrm{~cm}$-thick sill is observed at the lithological contact on either flank of Maio that obstructs direct observation of the sedimentary boundary with the overlying unit of non-calcareous, green-orange weathered, silicified mudstone of the Carquiejo Fm. This 4-5 m thick mudstone unit is commonly heavily fractured and has no internal structure, bar a singular $30 \mathrm{~cm}$-thick limestone bed. 
RDM-68 records a non-calcareous mudstone of the Carquiejo Fm, with no visible lamination and minor organic matter (see supplementary data Fig. S2).

Above this unit, the Carquiejo Fm. is typically heterogeneous, composed of thin-bedded shales, siltstones and laminated limestones. Exposure is absent below a fence crossing the river (Lat.: $15.18430^{\circ}$, Long: $-23.20428^{\circ}$ ), where the stratigraphy is folded and heavily eroded.

The non-calcareous mudstones are interpreted as being deposited below the CCD with a marked increase in terrigenous input from the NWAAM. Presence of wood material (see Section 4.3.1) in these deposits supports this interpretation. During diagenesis, reducing conditions prevailed as the facies has a ferruginous staining. The overlying heterogeneous unit was deposited by turbidity currents relatively rapidly in comparison to the pelagic Morro Fm.

\section{Ammonite Biostratigraphy}

The following biostratigraphic interpretation is based on the re-examination of the material collected and published by Stahlecker (1935). The ammonite collection made by Stahlecker (1935) originates from the upper part of the Morro Fm. (levels I to V) and the Upper Transition Unit (levels VII to XIV) (Fig. 5). The uppermost part of the Morro Fm. is marked by a barren interval. 


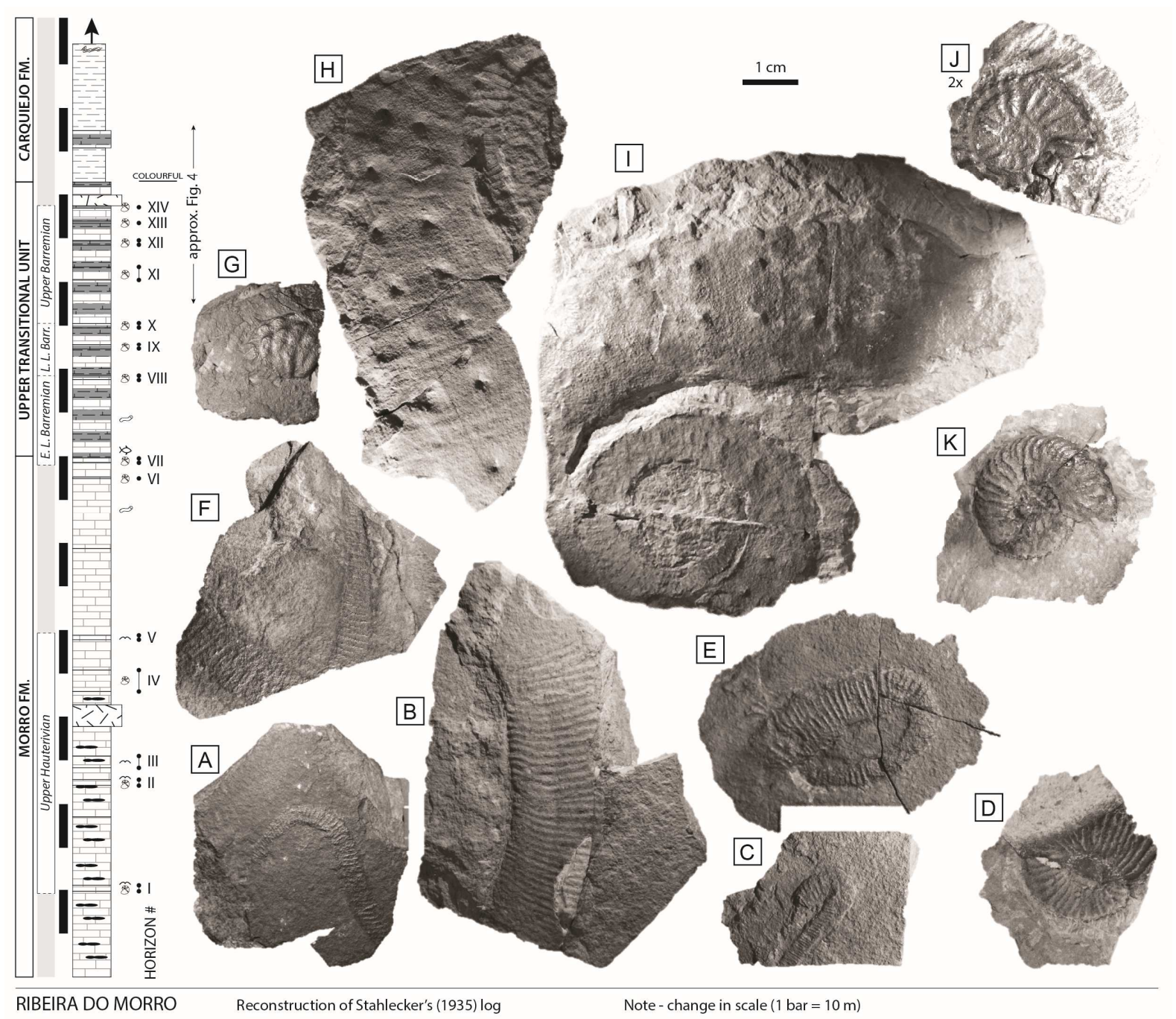

Fig. 5 - Reconstructed sedimentary log of the complete Ribeira do Morro section after Stahlecker (1935) with macrofossil horizons (I - XIV) displayed. The approximate stratigraphic location of Fig. 4 is shown. A selection of the key ammonites are illustrated: (A) VII - Leptohamulina cf. distans (= Leptoceras aff. sabaudianum in Stahlecker, 1935); (B) VII - Lytocrioceras sp. (= Ancyloceras sp. in Stahlecker, 1935); (C) VII - Mascarellina gr. hamus (= Hamulina cf. hamus in Stahlecker, 1935); (D-E) VII - Eoheteroceras multicostatum (= Heteroceras giraudi in Stahlecker, 1935); (F) VII - Eoheteroceras multicostatum (= Heteroceras aff. heterocostatum in Stahlecker, 1935); (G) VIII - Pulchellia sp. (= Pulchellia rhombocostata in Stahlecker, 1935); (H, I) X-Toxancyloceras gr. vandenheckii (= Ancyloceras matheronianum in Stahlecker, 1935); (J) XI - Heinzia sp. (= Douvilleiceras irregulare in Stahlecker, 1935); (K) XII - Heinzia sp. (= Pulchellia hoplitiformis in Stahlecker, 1935). Location detailed in Fig. 1B and key in Fig. 4. Note the change in scale, each bar represents $10 \mathrm{~m}$. All ammonites are natural size except Fig. J. (x2).

Stahlecker's original material is preserved in the Palaeontological collections of the University of Tubingen (Germany) but most of the specimens that were re-examined in the late 1980's by the late Robert Busnardo (Fourcade et al., 1990) from the Morro Fm. are missing.

Based on Busnardo's interpretation of the fauna, Fourcade et al. (1990) assigned a late Hauterivian age to this interval. Even so we could not access the material, we support this view since level I to $V$ are 
characterized by the occurrence of fairly abundant Didayilamellaptychus of the angulicostatus group, including the type specimen of Didayilamellaptychus atlanticus (Hennig, 1914). It is clearly established that these taxa characterise the Upper Hauterivian (Měchová et al., 2010; Vašíček et al., 2016). We also agree with Fourcade et al. (1990) that the ammonoids from the topmost Morro Fm. (level VI) are not diagnostic.

The overlying level VII is marked by a fairly diverse fauna dominated by heteromorphic ammonoids. The overall preservation as crushed impressions, is fairly poor, but was thought sufficiently distinctive by Stahecker to allow the introduction of new taxa such as Heteroceras multicostatum, Toxoceras filicostatum, Ancyloceras maioense and Bochianites hennigi.

According to Busnardo in Fourcade et al. (1990), these forms should be re-interpreted as an assemblage of Sabaudiella (= Eoleptoceras in Fourcade et al., 1990), Acrioceras and Hamulina of late Hauterivian age. In our opinion this view is to be reconsidered in the light of the extensive recent literature on the upper Hauterivian and lower Barremian heteromorphic ammonoids (see references in Klein et al., 2007; Vermeulen, 2010a; Vermeulen et al., 2014; Leroy et al., 2016). The most significant taxa are illustrated on Fig. 5A-F.

In our views, the genus Lytocrioceras as interpreted by Delanoy and Poupon (1992) and Ebbo et al. (1999) is represented by open spires (such as T. filicostatum) and large proversum fragments (Fig. 5B and $A$. maioense). Heteroceras multicostatum has been variously interpreted in the literature (see comments in Vašičcek and Wiedmann, 1994; Vašiček \& Klajmon, 1998). In our opinion, it should rather be included in Eoheteroceras and it is closely allied to E. norteyi (Myczyński and Triff).

The fauna also includes a number of small sized Anahamulinidae that show two distinct morphologies. The smaller forms (Fig. 5C) are close to Mascarellina hamus (Quendstedt). The highly divergent shaft and proversum of the larger forms (Fig. 5A \& F) recalls Leptohamulina distans (Vašíček), and to a lesser extent, Vasicekina autinae (Vermeulen). Due to the state of preservation of the Maio specimens, full identity cannot be established, but the overall morphology is that of Leptohamulina. It should be noted that a fairly similar specimen was illustrated by Myczyński and Triff (1986, pl. 3, Fig. 10), and as a whole the assemblage from level VII is very similar to the fauna from the Polier Fm. of Cuba. Based on the known occurrence of Lytocrioceras in France and Eoheteroceras in Cuba, we retain an early Barremian age for this assemblage. The occurrence of Lytocrioceras strongly suggests that the association cannot be any older than the K. nicklesi ammonite Zone.

The occurrence of Pulchelliidae from level VIII to level XIV is of major biostratigraphic significance. Three representative specimens are illustrated herein (Fig. 5G, J and K). Identification at the species level is 
handicapped by the preservation of the material but we are confident that the ornamental features are those of the late early (level VIII) to early late Barremian (level X to XIV) forms of the genera Pulchellia (Fig. 5G) and Heinzia (Fig. 5J-K) (Vermeulen, 2003; Patarroyo, 2004). The base of the upper Barremian is placed at level $X$ based on the occurrence of Toxancyloceras of the vandenheckii group (Fig. $5 \mathrm{H}-\mathrm{I}$ ) (Delanoy, 2003; Bert et al., 2018).

\section{Calcareous Nannofossil Biostratigraphy}

The basal intercalated mudstones from the Morro Fm. sampled between RDM-27 and RDM-38 are extremely poor, no age assigned (Fig. 4 \& Table S1). Nannofossil recovery improves from RDM-40 upwards within the upper part of the Morro Fm. A poorly preserved, moderate diversity assemblage yields Zeugrhabdotus scutula, Assipetra terebrodentarius youngii and Nannoconus steinmannii. This association is indicative of a latest Barremian through earliest Aptian age. Above sample RDM-51, nannoconid abundance drops significantly with $N$. steinmannii only sporadically identified (RDM-63 \& RDM-66). Conusphaera rothii is not recorded from this section, this probably more of a preservational response than a true stratigraphic event.

The Carquiejo Fm yields a low diversity assemblage characterised by the continued occurrence of $A$. terebrodentarius youngii and the appearance at RDM-70 of Eprolithus floralis (Fig. 4 \& Table S1). The presence of these two markers indicate a lower Aptian to earliest Albian age range. Preservational bias affects the actual top/base of nannofossil events, rather than true FO/LO. 


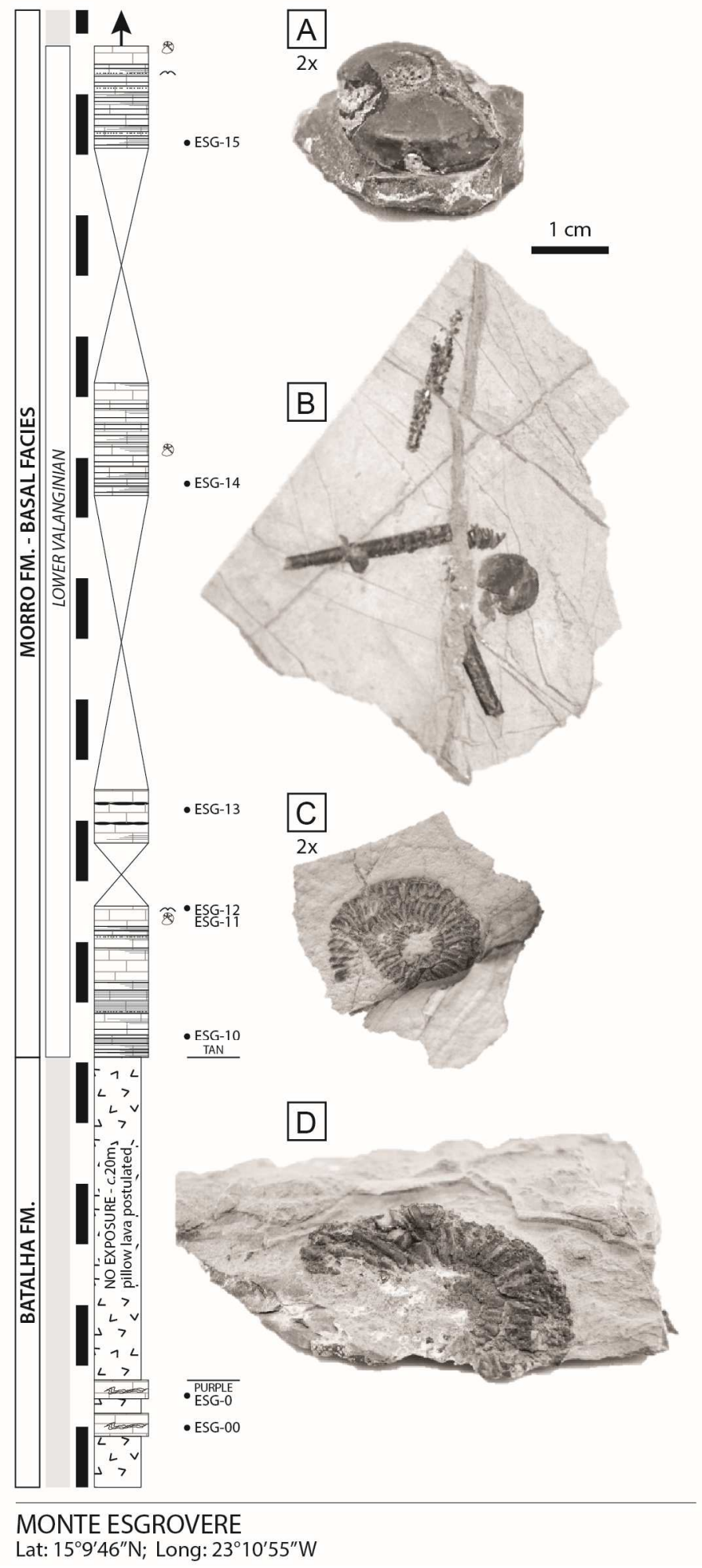

Fig. 6 - Detailed sedimentary log of the Monte Esgrovere section with photographs of the new collection of ammonites: (A) Neolissoceras (Vergoligeras) sp. juv. gr. salinarium; (B) Bochianites sp.; (C) "Busnardoites" sp.; (D) Kilianella sp. All ammonites are natural size except Fig. A and C (x2). Location detailed in Fig. 1B and key in Fig. 4. 
Patchy exposure across the Monte Esgrovere hillside can be correlated to produce a detailed log (Fig. 6), with the inferred igneous units in Fig. 4. At the location defined by Fourcade et al. (1990) there was no present-day surface exposure, with evidence of quarrying, hence a section was selected $1 \mathrm{~km}$ to the ESE (Lat.: $15.16296^{\circ}$, Long: $-23.18191^{\circ}$ ). This is the only location on the island preserving a complete section from Batalha Fm. lavas, through the basal ferruginous facies to the main pelagic limestones of the Morro Fm.

\section{Lithofacies}

\section{Batalha Formation}

Silicified limestone facies - The inter-lava sediments within the Batalha Fm. comprise red-purple silicified limestones and chert previously described by Fourcade et al. (1990). These are observed in two outcrops separated $5 \mathrm{~m}$ apart along strike, have a thickness of $c a .1 \mathrm{~m}$, interbedded with inferred pillow lavas (ESG-0, see supplementary data Fig. S2). The sediments show undulated bedding. Sample ESG-0 is a red ferruginous mudstone with a banded fabric (see supplementary data Fig. S2). The micritic matrix contains quartoze silt and calcified radiolarian, with a dark black band of opaque hematite. Above this, isolated exposure of the interlava sediments is $c a .20 \mathrm{~m}$ of poorly exposed pillow lavas. The contact between the Batalha and Morro Fm. is not directly observable, but is inferred as the break in slope before the more competent Morro Fm. limestone crops out.

Stillman et al. (1982) assumes that the variolitic texture of the pillow lava indicates eruption of the midocean ridge basalts between 1000-1500 m water-depth. In the latter episodic stages of pillow lava formation, silicified limestones accumulated above the CCD and were reworked by current activity during periods of volcanic quiescence.

\section{Morro Formation}

Ferruginous limestone facies - At this location, the basal limestone has weathered to a bright orange colour due to ferruginous enrichment (Stillman et al., 1982), gradually fading to the typical grey of the Morro Fm. The limestone is thickly bedded, occasionally with finely laminated, mm-scale, horizons of iron concretions, containing a diverse macro-fossil assemblage. Thin sections of two samples from this interval show different characteristics. Sample ESG-12 has a mudstone texture containing thin-shelled bivalve fragments and recrystallised radiolaria (see supplementary data Fig. S2). This microfacies shows a nodular pseudo-laminated fabric with abundant dark, wavy seams of organic material. Sample ESG16 has a similar microfacies (top and base; see supplementary data Fig. S2) punctuated by a normallygraded bed, where the boundary appears stylolitized. Micro-faulted calcite veins cross-cut the sample. 
A thin intraformational conglomerate is present within the basal facies containing rounded clasts of altered volcanic glass and pellets of chlorite in a ferruginous micritic matrix (Robertson, 1984). The transition to typical Morro Fm. limestones is gradual observed along the exposure as it continues across the hill, where surface mining is currently active.

The pelagic limestones formed in a hydrothermal field active during and sometime after the latter stages of volcanism, causing metalliferous enrichment that gradually waned (Stillman et al. 1982). Robertson (1984) highlights the geochemical similarities between this Fe-enriched and Al-depleted facies and oceanic pelagic sequences in the Pacific seamount chains, but suggests deposition occurred in a topographic low evidenced by laminated sedimentation.

\section{Biostratigraphy}

The newly collected material from the base of Morro Fm. is preserved as limonitic internal moulds of juveniles. It includes Vergoliceras of the salinarium group (Fig. 6A), Bochianites sp. (Fig. 6B), Kilianella sp. (Fig. 6D), olcostephanids, and a poorly preserved neocomitid that is tentatively assigned to "Busnardoites" sp. (Fig. 6C). Co-occurrence of Vergoliceras and Kilianella leaves no doubt about the middle early Valanginian age of the assemblage (Neocomites neocomiensiformis Zone, see Company and Tavera, 2015 with references).

Re-evaluation of the calpionellid illustrated by Fourcade et al. (1990) by Daniela Reháková (pers. comms. 2019) suggests that the Calpionellites species identified by those authors rather marks the upper part of the Calpionellites Zone, e.g. the Major Subzone. This subzone indicates the middle to late Lower Valanginian (Petrova et al., 2011), supporting the age assignment from the ammonite biostratigraphy. 


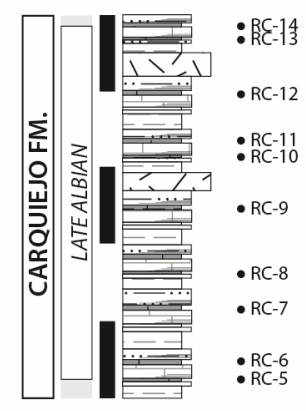

RIVER CUT

Lat: $15^{\circ} 11^{\prime} 4^{\prime \prime} \mathrm{N}$; Long: $23^{\circ} 12^{\prime} 17^{\prime \prime} \mathrm{W}$

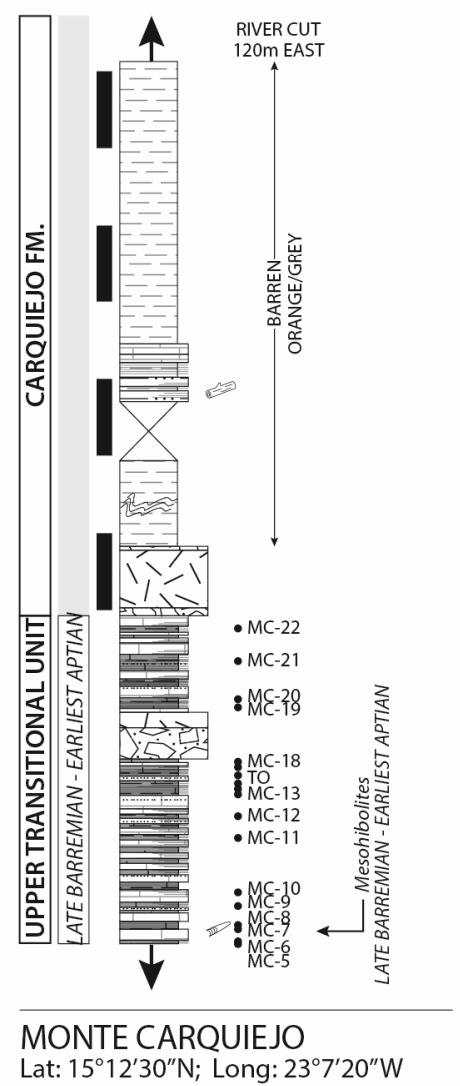

Fig. 7 - Detailed sedimentary log of the Monte Carquiejo and River Cut section, separated by approximately $120 \mathrm{~m}$. Samples taken for the calcareous nannofossil biostratigraphy are annotated and the distribution charts are provided in the supplementary data (Table S1). One belemnite was identified and studied; the location in the stratigraphy is shown supporting the age interpretation from the calcareous nannofossils. Location detailed in Fig. 1B and key in Fig. 4.

Lithofacies

Located northwest of Monte Carquiejo (Lat.: $15.20829^{\circ}$, Long: $-23.12218^{\circ}$ ), the Morro and Carquiejo Fm. boundary is well exposed for ca. $10 \mathrm{~m}$ in a small stream valley (MC; Fig. 7). The upper transitional unit and Carquiejo Fm. has many similarities to the Ribeira do Morro section (RDM). 
The upper transitional unit is composed of cyclic bedded small packages (av. $20 \mathrm{~cm}$ thick total) of bituminous dark grey calcareous mudstones, interbedded with very thin $(<5 \mathrm{~mm})$ beds of limestone. Limestone content increases upward, cumulating in a massive flaggy limestone (av. $10 \mathrm{~cm}$ thick). These thin-bedded limestones contain numerous horizons of $\mathrm{mm}$-scale iron concretions, some of which are lenticular in shape. A belemnite-rich horizon is recorded within this unit that can be correlated around the flank of Monte Carquiejo. At this location a sill is also intruded at the contact between the formations. The stratigraphy appears conformable, with no apparent change in the dip of the bedding (see supplementary data Fig. S3B). The overlying Carquiejo Fm. is again heterogeneous; comprising lowermost beds of non-calcareous weathered-orange blocky mudstone up to $1.5 \mathrm{~m}$ in thickness. A small package of thin-bedded limestone sits above this, where a $20 \mathrm{~cm}$ long piece of wood debris was observed (see supplementary data Fig. S3C).

Exposed across the NE slopes of Monte Branco and Monte Carquiejo, along strike from the Monte Carquiejo section (MC) and down dip within the main Morro Fm., a distinct $30 \mathrm{~cm}$-thick bed of pale orange to tan limestone has a moderately preserved assemblage of trace fossils on the dolomitized base of the bed (see supplementary data Fig. S3D-E). Narrow 1-3 mm in diameter, non-branching, structureless Planolites burrows are relatively abundant. Larger $>10 \mathrm{~mm}$ in diameter, Y-branched Thalassinoides burrows are postulated. At the Monte Carquiejo section (MC), in bed MC-7 within the upper transitional unit, narrow $<1 \mathrm{~mm}$ in diameter, $\mathrm{Y}$-shaped branching Chrondrites burrows weather a dark orange colour in comparison to the grey limestone sediment (see supplementary data Fig. S3F). Collectively, these trace fossils likely represent the Nereites ichnofacies and consequently, is the first ichnofacies description from Maio providing evidence of a deep offshore marine palaeo-environment (after Gerard \& Bromley, 2008).

Approximately $120 \mathrm{~m}$ east (Lat.: $15.18457^{\circ}$, Long: $-23.20481^{\circ}$ ), the Carquiejo Fm. crops out in the eroded river bank (RC), this is the youngest stratigraphy analysed in the paper (Fig. 7). The section ca. $5 \mathrm{~m}$ thick is heterogeneous composed of thin-bedded limestones, non-calcareous and calcareous mudstones. Above this, a band of white stained debris appears in the river bank, which is thought to represent heavily eroded bleached black shales.

\section{Biostratigraphy}

Sixteen samples from the marls of the upper transitional unit of the Morro Fm. were investigated. All yielded low diversity assemblages characterised by Assipetra terebrodentarius and $A$. terebrodentarius youngii, its presence indicating an age no older than latest Barremian (Fig. 7 \& Table S1). Nannoconus spp. are rare throughout the section and not recorded above MC-12. Nannoconus steinmannii is 
restricted to the bottom sample analysed, MC-5. Isolated occurrences of Zeugrhabdotus scutula are recorded from samples MC-12 and MC-17 and indicate an age no younger than earliest Aptian. Conusphaera rothii was not recorded from the Monte Carquiejo samples analysed, this considered more a reflection of poor recovery than absolute stratigraphic ranges.

The belemnites recovered from the upper transitional unit are juvenile forms most probably Mesohibolites, although not identifiable at the species level (Fig. 7). This genus has an age range from the late Barremian to earliest Aptian and is supportive of the MC nannofossil datings.

The youngest Cretaceous succession with nannofossil recovery was investigated at the Monte Carquiejo River Cut (RC). Nine samples were analysed, two samples barren of nannofossils (RC-11 \& RC14), the remainder yielding a poorly preserved, moderate diversity assemblage (Fig. 7 \& Table S1). The presence of Eiffelithus turriseiffelii in the absence of Gartnerago nanum / G. theta, Acaenolithus cenomanicus and the Broinsonia signata / B. enormis plexus indicates a stratigraphic level within the upper part of the late Albian. Additional support for this age assignment is provided by the presence of Hayesites albiensis in the basal sample RC-5 and occurrence of Watznaueria britannica (samples RC-7 \& RC-10), both species having documented LAD's close the top Albian.

Sample RC-6 produced very abundant planktonic foram chambers observed semi-buried in lithic fragments. Despite lithic material remaining attached to the specimens, Globigerinelloides and Hedbergella are identified, although unidentifiable at a species level are consistent with the late Albian age assigned. There is one specimen resembling $G$. bentonensis which is not older than mid-late Albian. The abundance of the planktonics (which is high) suggests strong, open ocean, well oxygenated marine conditions within the upper water column. 


\section{Discussion}

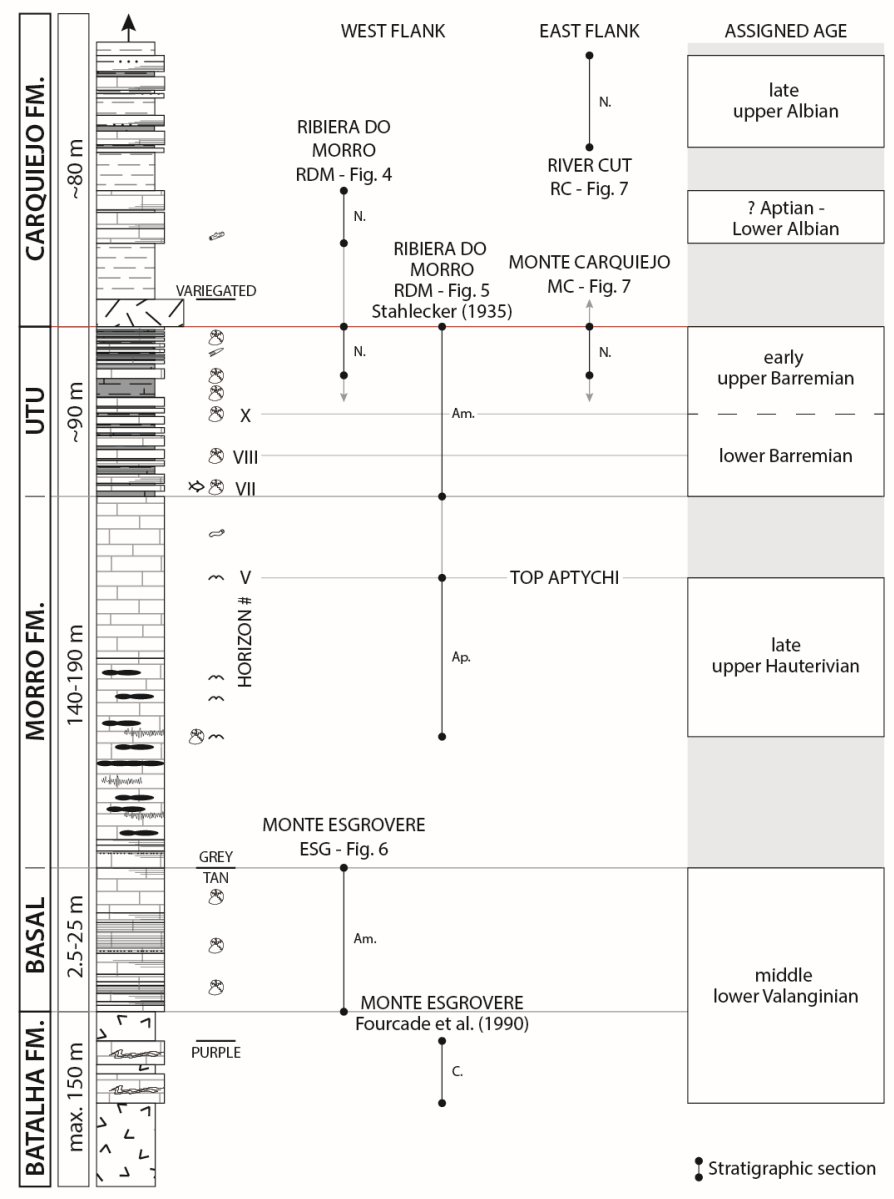

Fig. 8 - Composite stratigraphic summary log of the Cretaceous succession of Maio integrating all new data from various sections documented (Figs. 4 - 7), with the calpionellid dating of the Batalha Fm. by Fourcade et al. (1990). UTU - upper transitional unit of the Morro Formation; Dating of sections based on: N. - nannofossils; Am. - ammonites; Ap. - aptychi; C. - calpionellids.

\section{Stratigraphy}

Despite previous efforts the stratigraphy of Maio has remained poorly dated and significant uncertainties have persisted throughout publications. Our comprehensive analysis of new fieldwork data complementing an exhaustive re-interpretation of existing data has contributed towards resolving these issues and improving the stratigraphic resolution (Fig. 8). The unpublished geological report of Rigassi (1972) underpins the dating of the sedimentary sequence of Maio and was studied as part of our analysis. The ages assigned to the stratigraphy are not supported by any macro-/micro-fossil plates or sedimentary logs leaving little scientific value for use in this paper. One of the uncertainties regards the Tithonian age reported in the literature for the lowermost stratigraphy exposed on the East flank of Maio. Our study joins Robertson and Bernoulli (1982), Stillman et al. (1982), Robertson (1984) and Fourcade et al. (1990) in recognising the absence of any Jurassic paleontological evidence to support 
this interpretation. The new ammonite assemblage documented at ESG, complementing the calpionellid dating of Fourcade et al. (1990) validates that the interlava sediments of the Batalha Fm. and overlying basal facies of the Morro Fm. are Lower Valanginian in age, part of the Neocomites neocomiensiformis Zone. This is in agreement with the positions of magnetic anomalies M11 and M16 relative to Maio (Fig. 1A).

Age definition for the upper transitional unit of the Morro Fm. is now robust; independent palaeontological analyses of sections on each flank of the island provide strong evidence of a late Barremian age, even so an early Aptian age cannot be excluded for the top of formation. Our new dating of the Carquiejo Fm. supports the Albian age interpretation of Fourcade et al. (1990), and as a consequence, the recognition of a hiatus or discontinuity spanning part of the Aptian and separating the contrasting lithologies of the Morro and Carquiejo Formations (Stillman et al. 1982). Our youngest age attributed to the Carquiejo Fm. from the RC section is of Late Albian age. This is not representative of the true youngest age for the formation as stratigraphy exposed higher up in this formation yielded no age data, and in addition, the overlying unconformity may have eroded section. Therefore, we are unable to determine the youngest age for the Carquiejo $\mathrm{Fm}$. and hence, the possible oldest most age for the volcanism on Maio due to the volcanic origin of the overlying Coruja Fm.

\section{Regional Correlation}

By correlating the results from Maio to additional data available in the Central Atlantic (DSDP results, outcrops in Cuba and more generally to the Maiolica facies of the Western Tethys) allows the Maio sediments to be considered within a regional context. DSDP Site 367 is the nearest penetration (ca. 450 km SE, Fig. 1B) of the Cretaceous stratigraphy (Lancelot et al. 1976). A comparison of stratigraphic thickness is not directly proposed due to the imprecision of measurements on Maio. However, Ali et al. (2003) highlight from seismic reflection data that this package thickens from west to east in response to sediment loading and flexure at the West African continental margin. As such a thinning from Site 367 (ca. $225 \mathrm{~m}$ ) to Maio is postulated, but may not be representative as DSDP Site 367 was drilled on a structural high (Lancelot et al. 1976). As discussed by Robertson (1984), red-brown argillaceous limestone facies encountered at Site 367 (Unit 6; "Rosso Ammonitico" sensu Farinacci \& Elmi, 1981) below the white nannofossil limestones (Unit 5) were not recognised on Maio (Lancelot et al. 1976). In light of the biostratigraphic results for the lowermost stratigraphy indicating a Lower Valanginian age (see Section 4.2.2) we would not expect to encounter these Jurassic sediments on the island.

The pelagic deep water limestones with chert of the Morro Fm. resemble lithologically, paleontologically and stratigraphically the Maiolica facies of the Western Tethys and Atlantic 
(Wieczorek, 1988), and are drilled across the Central Atlantic by the DSDP (Müller et al. 1983). Generally, the Maiolica facies is white to grey, compact, well stratified, pelagic limestone with dark nodular/layered chert, structured in 5-30 $\mathrm{cm}$ thick beds with little internal bedding due to intense bioturbation (Wieczorek, 1988). Lithological variations exist, exemplified by the comparison of stratigraphically equivalent Maio sediments to Unit 5 of DSDP Site 367 where marl interbeds are more common, related to the relative proximity to terrigenous supply from the NWAAM. Aptychi dominate the macro-fossil assemblage of the Maiolica facies and as such are prevalent in Unit 5 (DSDP Site 367; Renz, 1983) and observed in the Morro Fm. The Polier Fm. exposed on Cuba offers the nearest outcrop occurrence of a similar sedimentary sequence to the Morro Fm. (Pszczółkowski \& Myczyński, 1999), albeit there is an overprint of clastic turbidite sandstones. There is a strong resemblance between the facies, ammonite fauna and associated preservation style as once the Central Atlantic is reconstructed to Lower Cretaceous times, the sediments now exposed on Maio and Cuba would have been deposited at similar paleo-latitude and water depth (Davison, 2005).

The upper transitional unit records a discernible shift in the sedimentation style from the main Morro Fm. as more clay is introduced into the Central Atlantic and anoxic conditions commence (Chamley et al. 1988). This is reflected in the top of Unit 5 (Core 25 to 26, DSDP Site 367; Lancelot et al. 1976) where light grey limestones interbedded with olive black marl were encountered. Similarly this transitional facies is cropping out within the upper Polier Fm. (Pszczółkowski, 1978), and more widespread across both margins of the Tethys, Alps, Central Atlantic and Pacific (de Graciansky et al. 1981). On Maio, the Morro-Carquiejo sharp transition between calcareous and argillaceous dominated facies is clear. This, along with the biostratigraphy results, supports the interpretation of a regional hiatus recorded in the Western Tethys and Central Atlantic between the latest Early Aptian into the Late Aptian to Albian interval (Event E1 - Müller et al. 1983). Robertson (1984) generally links the overlying Carquiejo Fm. stratigraphy to the upper Mid-Cretaceous black shale facies drilled at DSDP Sites 367 and 368, whilst we agree with this broad interpretation further definition is possible. The non-calcareous claystones exposed at both the RDM and MC sections are seen as equivalent to the facies encountered in Core 24, DSDP Site 367 and not penetrated at DSDP Site 368 (Lancelot et al. 1976). The limited exposure of the upper Carqueijo Fm. prevents complete integration with the DSDP results; however the late Albian RC section is likely to be a distal equivalent of this upper Mid-Cretaceous black shale facies.

\section{Paleo-Environmental Evolution}

Ocean floor formation occurred during the lower Valanginian above the CCD, where interlava sediment was able to develop in quiescence periods of volcanism. The similarities in age between the interlava sediments (Fourcade et al. 1990) and basal Morro Fm. suggests that there was no break in 
sedimentation. A prolonged period of terrigenous starvation occurred extending from the lower Valanginian to Hauterivian resulting in the deposition of thick pelagic limestones in a deep water basinal environment. During this period, aggradational carbonate platforms extending around the circumference of the Central Atlantic were the focus of sedimentation preventing terrigenous material reaching the deep basin (Mourlot et al. 2018). The Morro Fm. pelagic limestones and Maiolica facies were deposited above the aragonite compensation depth (ACD) and above the CCD, due to the occurrence of calcitic aptychi and ammonites, both having aragonitic shells, in a basin starved of terrigenous input. Wieczorek (1988) highlights that these observations do not specify paleo-water depths, as suggested by Robertson (1984). Benthic life in the deep water basinal environment is indicated by the ichnofacies observed within the Morro Fm.

The presence of black shale facies interbedded in the upper transitional unit is not supported by TOC measurements, however the presence of fish remains and planktonic ammonites hints to dysoxic conditions. The co-occurrence of ornamented pulchellids and heteromorphic ammonoids is most typical of the shaley interlayers within the Maiolica facies (Cecca et al. 1995). The faunal assemblages are largely dominated by small size heteromorphs, a morphology that is known to indicate dysaerobic environments (see discussion in Frau et al. 2016). Organic geochemical analysis of the equivalent section at DSDP Site 367 reveals a high TOC content, 4-25\% within the marls (Lancelot et al. 1976); as such this anoxic environment is postulated in the upper transitional unit during the upper Barremian.

The regional hiatus occurs in a variety of depositional settings from carbonate platforms to pelagic environments, recording a significant facies contrast that is attributed to the raising of the CCD in response to a sea level-rise (Hancock, 1975; Vail et al., 1980; de Graciansky et al., 1981), and occurs coevally with the rifting phase in the North Atlantic and Equatorial Atlantic (Sibuet et al., 1980; Olyphantet al., 2017). The introduction of terrigenous material in the lower Carquiejo Fm. and identified in DSDP Site 367 (Core 24) corresponds to the increased delivery of argillaceous sediment by shelf edge deltas along the NW African Atlantic margin (Luber et al., 2019; Mourlot et al., 2018), introducing abundant plant debris. Evidence for early volcanism in the Cape Verde archipelago was suggested by the presence of tuffs within the Carquiejo Fm. (Serralheiro, 1968, 1970); however our field work supports Robertson's (1984) lack of identification of volcanic material in the formation. Consequently we follow previous interpretations that volcanism began in Paleogene to Miocene times. Although, the possibility is not dismissed as Van de Bogaard (2013) dates 4 seamounts of Lower Cretaceous age (142$119 \mathrm{Ma}$ ) using ${ }^{40} \mathrm{Ar} /{ }^{39} \mathrm{Ar}$ ratios within the Canary Island Seamount Province, and volcanic glass is present in Late Cretaceous to Tertiary succession of DSDP Site 368 (Lancelot et al. 1976). 


\section{Conclusions}

This multi-disciplinary study has revised the stratigraphy for the Cretaceous sediments exposed on Maio and provides a key section to define the stratigraphic framework in the distal domain of the Central Atlantic. Dating of a new collection of ammonites from the basal Morro Fm. definitively indicates a lower Valanginian age for the oldest sediments on Maio, revising the previous interpretations of a Jurassic age. The ferruginous limestone facies were deposited by pelagic processes in a metalliferous hydrothermal field resulting in Fe-enrichment. Re-interpretation of the original collection of macrofauna collected by Stahlecker was undertaken, essential to any stratigraphical study of these sediments, as this collection is likely to be irreplaceable due to intensive quarrying on the island. Combined with the first substantial nanno-fossil study of 71 samples and integration with new macro-fossils collected as part of this study, a refined stratigraphy is proposed for the Morro Fm. This suggests the youngest Morro Fm. is of upper Barremian age. The evolution from the main Morro Fm. massive to bedded limestone facies to the upper transitional unit flaggy limestone facies is a result of increasing terrigenous supply.

Our new dating of the Morro-Carquiejo boundary and facies observations support the presence of a major regional hiatus spanning part of the Aptian. This can be recognised widely across the Central Atlantic as it is proposed to be related to major geodynamic events in the Atlantic and associated changes in oceanic conditions. The youngest studied stratigraphy, the Carquiejo Fm., correlates well with the middle Upper Cretaceous black shale facies drilled during DSDP expeditions across the Central Atlantic. These record bleached black shale facies indicative of anoxic depositional environment. The organic content of the mudstones on Maio is absent, most probably significantly degraded due to thermal alteration associated with the volcanic activity and prolonged exposure at outcrop. Future biostratigraphical studies should aim to date the uppermost Carquiejo Fm. and overlying Coruja Fm. to deduce the earliest possible age for the volcanism related to the formation of this unique island and the remainder of the archipelago.

\section{Acknowledgements}

This study is part of the lead authors PhD project at the University of Manchester, I thank the additional authors for their support and encouragement. We thank the sponsoring companies of NARG for their continued financial, logistical, and scientific support. The paper is dedicated to Chris Cornford who along with Steve Lawrence paved the way for the field investigation. Mike Bidgood (GSS Geoscience Ltd.) and Nico Janssen (TNO) are thanked for their contributions towards the foraminifera and belemnite analysis respectively. We also thank Dr. Ingmar Werneburg from the Palaeontological 
Collection at the University of Tübingen for their hospitality and open access to the Stahlecker palaeontological collection. Elsa Bulot's support and photography of specimens in Tübingen is greatly appreciated. Prof. Alastair Robertson is acknowledged for helping access the report of Rigassi (1972). Richard Dixon (BP Exploration) is thanked for making us aware of the exceptional geology exposed on this island. Miguel Company (University of Granada, Spain), an anonymous reviewer and Gondwana Research associate editor, Andrea Festa's constructive reviews significantly improved this paper.

\section{References}

Ali, M.Y., Watts, A.B. and Hill, I., 2003. A seismic reflection profile study of lithospheric flexure in the vicinity of the Cape Verde Islands. Journal of Geophysical Research: Solid Earth, 108(B5).

Armstrong, H. and Brasier, M., 2013. Microfossils. John Wiley \& Sons.

Bert, D., Bersac, S., Ruiz, J., and Hughes, Z., 2018. Size reduction and ornamental oscillation within a Barremian lineage of giant heteromorphic ammonites (Early Cretaceous, northwestern Tethyan margin). Cretaceous Research 88, pp. 173-186.

Bown, P., 1998. Calcareous nannofossil biostratigraphy. Chapman and Hall; Kluwer Academic, pp. 1315.

Cecca, F., Faraoni, P., Marini, A. and Pallini, G. 1995. Fieldtrip across the representative sections for the Upper Hauterivian - Barremian ammonite biostratigraphy in the Maiolica exposed at Monte Nerone, Monte Petrano and Monte Catria (Umbria-Marche Apennines). Memorie descrittive della Carta Geologica d'Italia 51, pp. 187-211.

Chamley, H., Debrabant, P. and Flicoteaux, R., 1988. Comparative evolution of the Senegal and eastern central Atlantic basins, from mineralogical and geochemical investigations. Sedimentology, 35(1), pp. 85-103.

Company, M., and Tavera, J.M., 2015. Lower Valanginian ammonite biostratigraphy in the Subbetic Domain (Betic Cordillera, southeastern Spain). Carnets de Géologie 15/8, pp. 71-88.

Crough, S.T., 1978. Thermal origin of mid-plate hot-spot swells. Geophysical Journal International, 55(2), pp. 451-469.

Davison, I., 2005. Central Atlantic margin basins of North West Africa: geology and hydrocarbon potential (Morocco to Guinea). Journal of African Earth Sciences, 43(1-3), pp.254-274.

Delanoy, G., 2003. Toxancyloceras gen. nov. (Ammonoidea, Ancyloceratina) un nouveau genre du Barrémien supérieur. Annales du Museum d'Histoire Naturelle de Nice 18, 1-19.

Delanoy, G., and Poupon, A., 1992. Sur le genre Lytocrioceras Spath, 1924 (Ammonoidea, Ancyloceratina). Geobios 25/3, pp. 367-382.

De Graciansky, P.C., Bourbon, M., Lemoine, M. and Sigal, J., 1981. The sedimentary record of midCretaceous events in the western Tethys and central Atlantic Oceans and their continental margins. Eclogae Geol. Helv, pp. 353-367.

de Paepe, P., Klerkx, J., Hertogen, J. and Plinke, P., 1974. Oceanic tholeiites on the Cape Verde Islands: petrochemical and geochemical evidence. Earth and Planetary Science Letters, 22(4), pp. 347-354. 
Ebbo, L, Poupon, A., Delanoy, G., and Gonnet, R., 1999. Nouvelles données sur le genre Lytocrioceras Spath, 1924 dans le Barrémien inférieur du Sud-Est de la France. Annales du Museum d'Histoire Naturelle de Nice 14, 1-25.

Farinacci, A. and Elmi, S. eds., 1981. Edizioni Tecnoscienza.

Fourcade, E., Azéma, J., de Wever, P. and Busnardo, R., 1990. Contribution à la datation de la croûte océanique de l'Atlantique central: Age valanginien inférieur des basaltes océaniques et âge néocomien des calcaires Maiolica de Maio (Iles du Cap Vert). Marine Geology, 95(1), pp. 31-44.

Frau, C., Delanoy, G., Masse, J.-P., Lanteaume, C., Tendil, A.J.B., 2016. New Heteroceratidae (Ammonoidea) from the late Barremian deepening succession of Marseille (Bouches-du-Rhône, France). Acta Geologica Polonica 66(2), pp. 205-225.

Gerard, J. and Bromley, R., 2008. Ichnofabrics in clastic sediments: applications to sedimentological core studies (p. 100). Madrid: J. Gerard.

Gradstein, F.M., Ogg, J.G., Schmitz, M. and Ogg, G. eds., 2012. The geologic time scale 2012. elsevier. Hancock, J.M., 1975. The petrology of the Chalk. Proceedings of the Geologists'Association, 86(4), pp. 499-535.

Hayes, D.E. and Rabinowitz, P.D., 1975. Mesozoic magnetic lineations and the magnetic quiet zone off northwest Africa. Earth and Planetary Science Letters, 28(2), pp. 105-115.

Hennig, E. 1914. Aptychen von den Cap Verdeschen Inseln. Zeitschrift der Deutschen geologischen Gesellschaft, 65, pp. 151.

Holm, P.M., Grandvuinet, T., Friis, J., Wilson, J.R., Barker, A.K. and Plesner, S., 2008. An 40Ar-39Ar study of the Cape Verde hot spot: Temporal evolution in a semistationary plate environment. Journal of Geophysical Research: Solid Earth.

Jeremiah, J., 1996. A proposed Albian to Lower Cenomanian nannofossil biozonation for England and the North Sea Basin. Journal of Micropalaeontology, 15(2), pp. 97-129.

Klein, J., Busnardo, R., Company, M., Delanoy, G., Reboulet, S., Ropolo, P., and Vermeulen, J., 2007. Lower Cretaceous Ammonites III, Bochianitoidea, Protancyloceratoidea, Ancyloceratoidea, Ptychoceratoidea. In: Riegraf, W., Ed., Fossilium catalogus I: Animalia 144, pp. 1-381. Backhuys Publishers, Leiden.

Lancelot, Y., Seibold, E. et al., 1976. Initial Reports of the DSDP, Vol. 41. U.S. Government Printing Office, Washington, D.C., 1259 pp.

Leroy, L., Vermeulen, J., Lazarin, P., Lepinay, P., and Mascarelli, E., 2016. Nouvelles données sur la classification et l'évolution des Anahamulinidae Breistroffer, 1952 (Turrilitina, Ptychoceratoidea). Annales du Muséum d'Histoire Naturelle de Nice 31, pp. 1-25.

Luber, T.L., Bulot, L.G., Redfern, J., Frau, C., Arantegui, A. and Masrour, M., 2017. A revised ammonoid biostratigraphy for the Aptian of NW Africa: Essaouira-Agadir Basin, Morocco. Cretaceous Research, 79, pp. 12-34.

Luber, T.L., Bulot, L.G., Redfern, J., Nahim, M., Jeremiah, J., Simmons, M., Bodin, S., Frau, C., Bidgood, M. and Masrour, M., 2019. A revised chronostratigraphic framework for the Aptian of the EssaouiraAgadir Basin, a candidate type section for the NW African Atlantic Margin. Cretaceous Research, 93, pp.292-317.

Měchová, L., Vašíček, Z., and Houša, V., 2010. Early Cretaceous ribbed aptychi - a proposal for a new systematic classification. Bulletin of Geosciences 85/2, pp. 219-274. Czech Geological Survey, Prague. 
Mourlot, Y., Calvès, G., Clift, P.D., Baby, G., Chaboureau, A.C. and Raisson, F., 2018. Seismic stratigraphy of Cretaceous eastern Central Atlantic Ocean: Basin evolution and palaeoceanographic implications. Earth and Planetary Science Letters, 499, pp. 107-121.

Müller, C., Schaff, A. and Sigal, J., 1983. Biochronostratigraphy of Cretaceous Formations in DSDP boreholes in the North Atlantic 1. Revue de I'Institut Français du Petrole, 38(6), pp. 683-708.

Myczynski, R., and Triff, J., 1986. Los ammonites del Cretácio Inferior de las provincias de Pinar del Río y Matanzas. Bulletin of the Polish Academy of Sciences, Earth Sciences 34, pp. 113-137.

Olyphant, J.R., Johnson, R.A. and Hughes, A.N., 2017. Evolution of the Southern Guinea Plateau: Implications on Guinea-Demerara Plateau formation using insights from seismic, subsidence, and gravity data. Tectonophysics 717, pp. 358-371.

Patarroyo, P., 2004. Die Entwicklung der Ammoniten der Familie Pulchelliidae aus dem Barrême von Zentral-Kolumbien (Südamerika). Revue de Paléobiologie 23(1), pp. 1-65.

Petrova, S., Lakova, I., Ivanova, D., 2011. Berriasian-Valanginian boundary in Bulgaria. Review of the Bulgarian Geological Society 72(1-3), pp. 91-97.

Pim, J., Peirce, C., Watts, A.B., Grevemeyer, I. and Krabbenhöft, A., 2008. Crustal structure and origin of the Cape Verde Rise. Earth and Planetary Science Letters 272(1-2), pp. 422-428.

Pszczółkowski, A., 1978. Geosynclinal sequences of the Cordillera de Guaniguanico in western Cuba; their lithostratigraphy, facies development, and paleogeography. Acta Geologica Polonica 28(1), pp. $1-96$.

Pszczółkowski, A. and Myczyński, R., 1999. Nannoconid assemblages in Upper Hauterivian-Lower Aptian limestones of Cuba: their correlation with ammonites and some planktonic foraminifers. Studia Geologica Polonica, 114, pp. 35-75.

Renz, O., 1983. Early Cretaceous Cephalopoda from the Blake-Bahama basin (DSDP Leg 76, Site 534A) and their correlation in the Atlantic and southwestern Tethys. Sheridan, RE, and others, Initial reports of the Deep Sea Drilling Project, 76, pp.639-645.

Rigassi, D., 1972. Geology and oil prospect of Cape Verde Islands. In Report for the Oil Industry (p. 75). Petroconsultants Geneva.

Robertson, A.H.F., 1984. Mesozoic deep-water and Tertiary volcaniclastic deposition of Maio, Cape Verde Islands: Implications for Atlantic paleoenvironments and ocean island volcanism. Geological Society of America Bulletin, 95(4), pp. 433-453.

Robertson, A.H. and Bernoulli, D., 1982. Stratigraphy, facies, and significance of late Mesozoic and early Tertiary sedimentary rocks of Fuerteventura (Canary Islands) and Maio (Cape Verde Islands). In Geology of the Northwest African continental margin (pp. 498-525). Springer, Berlin, Heidelberg.

Serralheiro, A., 1968. Formações sedimentares do arquipélago de Cabo Verde.

Serralheiro, A., 1970. Geologia da Ilha de Maio (Cabo Verde). Junta de Investigações do Ultramar.

Seton, M., J. Whittaker, P. Wessel, R. D. Müller, C. DeMets, S. Merkouriev, S. Cande, C. Gaina, G. Eagles, R. Granot, J. Stock, N. Wright, and S. Williams (2014), Community infrastructure and repository for marine magnetic identifications. Geochemistry, Geophysics, Geosystems, pp. 1629-1641.

Stahlecker, R., 1935. Neocom auf der Kapverden-Insel Maio. Neues Jahrbuch für Geologie und Palaeontolgie, 73, pp. 265-301.

Stillman, C.J., Furnes, H., LeBas, M.J., Robertson, A.H.F. and Zielonka, J., 1982. The geological history of Maio, Cape Verde islands. Journal of the Geological Society, 139(3), pp. 347-361. 
Vail, P.R., Hardenbol, J. and Todd, R.G., 1984. Jurassic unconformities, chronostratigraphy, and sealevel changes from seismic stratigraphy and biostratigraphy.

Vašíček, Z. and Klajmon, P., 1998. Contribution to the knowledge of some small Early Barremian ammonites from the Silesian Unit (Outer Western Carpathians, Czech Republic). Věstník Českého Geologického ústavu, 73, pp.331-342.

Vašíček, Z., and Wiedmann, J., 1994. The Leptoceratoidinae: small heteromorph ammonites from the Barremian. Palaeontology 37/1, pp. 203-239.

Vašíček, Z., Janssen, N.M.M., and Klein, J., 2016. The chronostratigraphical record of Didayilamellaptychus (Lamellaptychi, Ammonitina). Neues Jahrbuch für Geologie und PaläontologieAbhandlungen 280/1, pp. 37-48.

Vermeulen, J., 2010a. Nouvelle tripartition de la famille des Anahamulinidae Breistroffer, 1952 (Turrilitina, Ptychoceratoidea) et description de quelques taxa du Barrémien inférieur du sud-est de la France. Annales du Muséum d'Histoire Naturelle de Nice 25, pp. 61-91.

Vermeulen, J., 2010b. Sur deux nouvelles espèces de la famille des Anahamulinidae Breistroffer, 1952. Riviera scientifique 94, pp. 107-116.

Vermeulen, J., Lazarin, P., Lepinay, P., Leroy, L., Mascarelli, E., 2014. Ammonites du Barrémien du sudest de la France. Strata, série 2, Mémoires 50, pp. 1-95.

van den Bogaard, P., 2013 The origin of the Canary Island Seamount Province - New ages of old seamounts. Sci. Rep. 3, 2107

Wieczorek, J., 1988. Maiolica - a unique facies of the Western Tethys. Annales Societatis Geologorum Poloniae, 58 (3-4), pp. 255-276. 
SUPPLEMENTARY DATA 


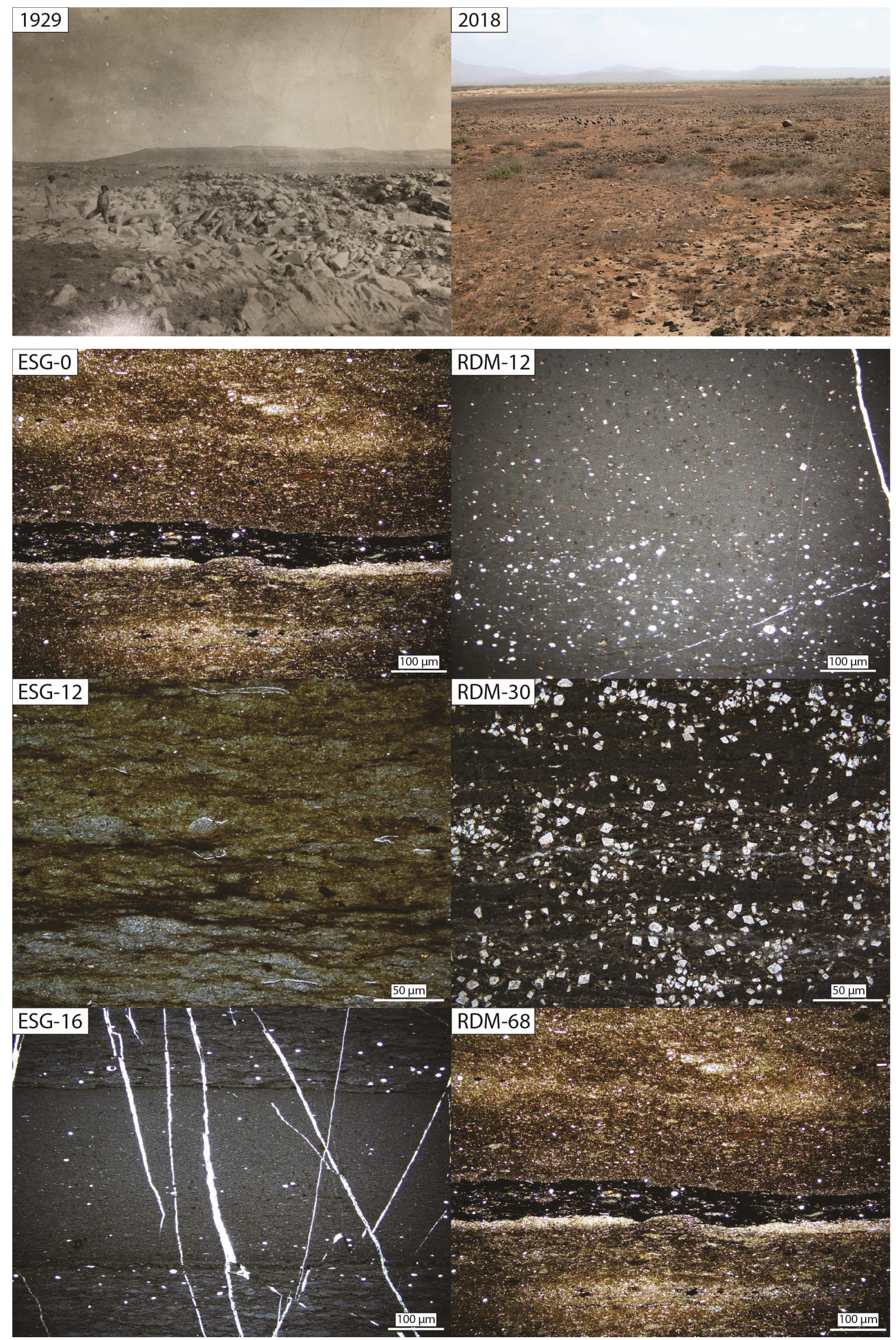




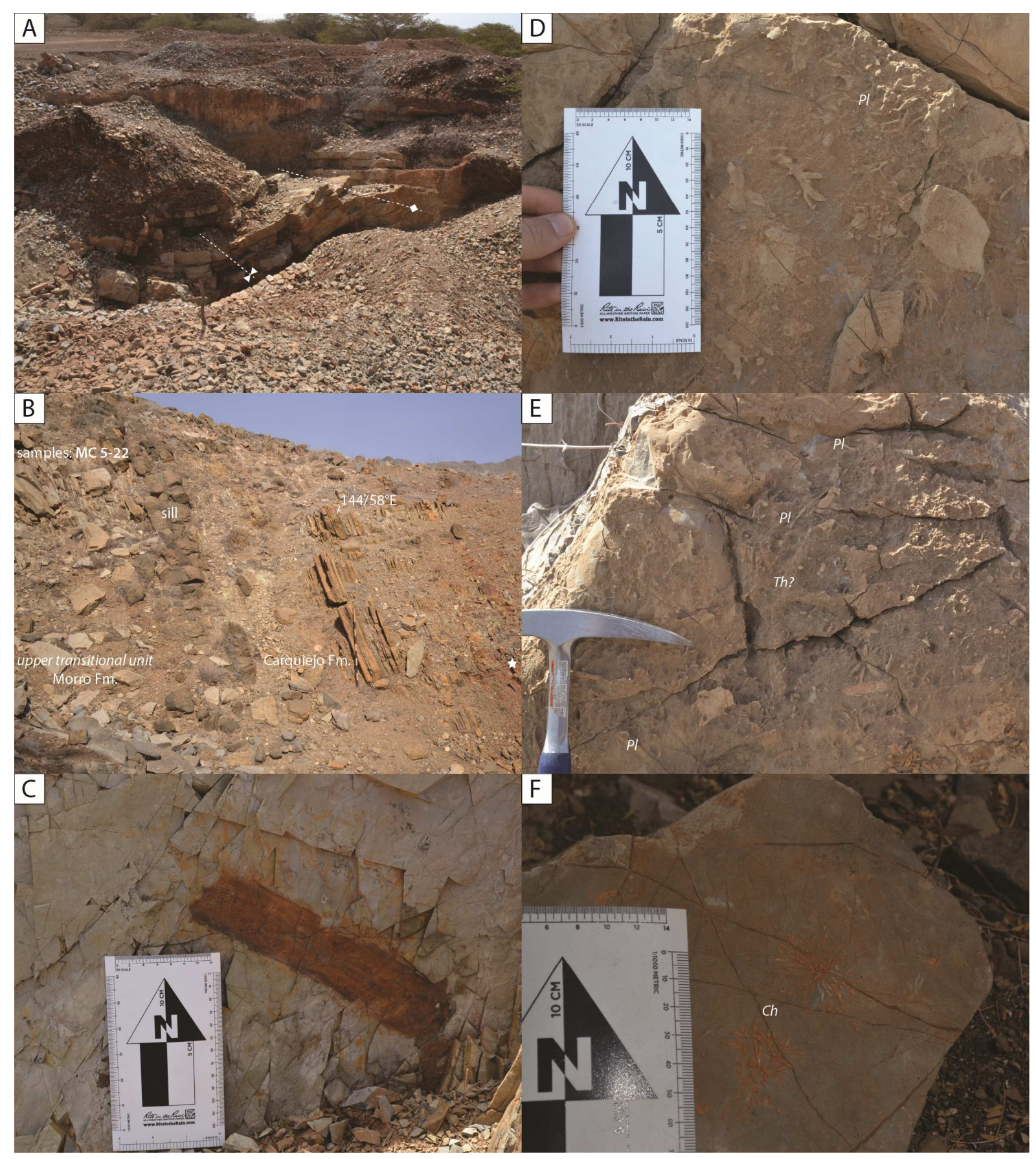




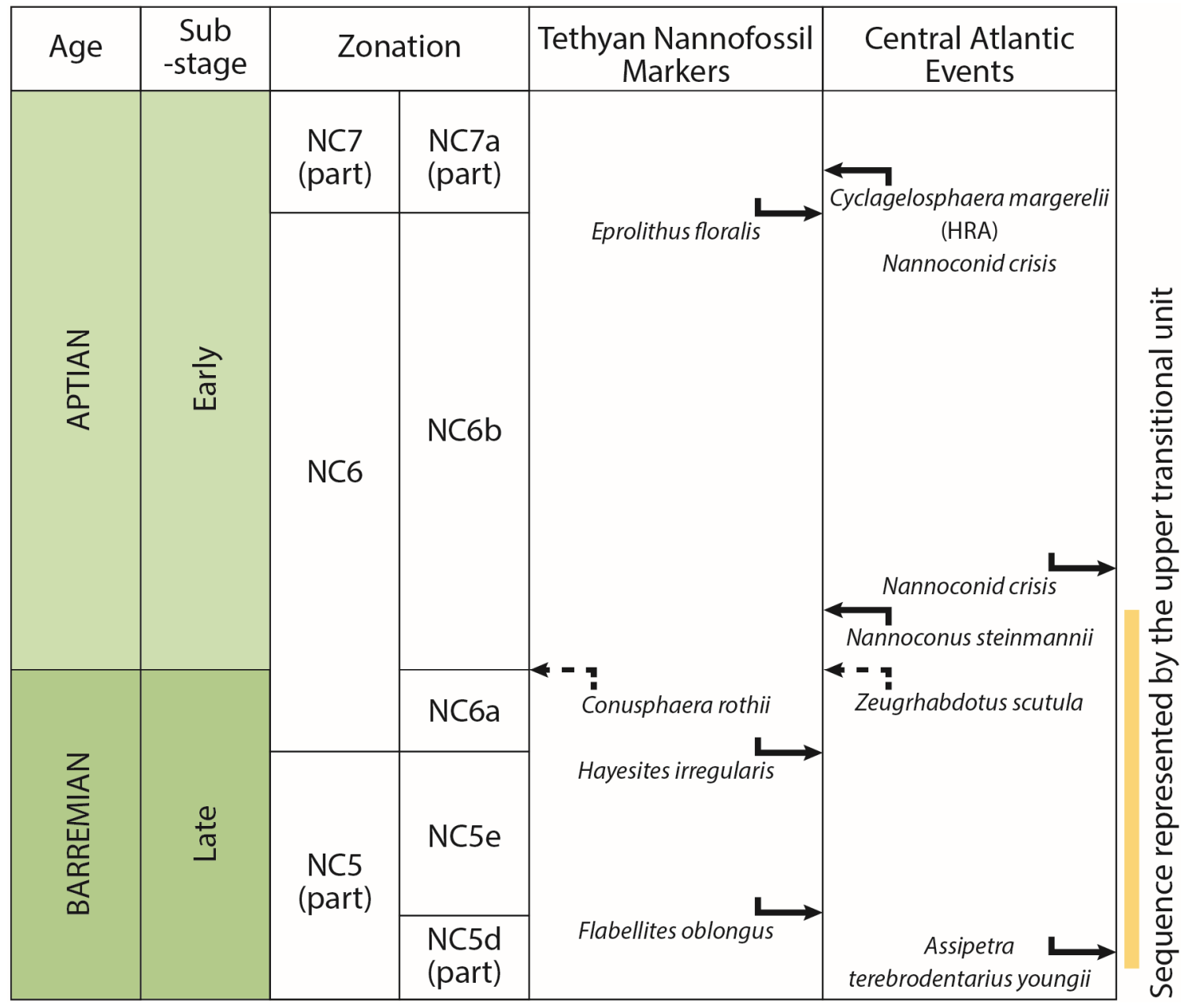

Fig. S1 - Photographs of the exposures at Ribiera do Morro showing the intense quarrying activities over the last century. Photograph from 1929 scanned from the Stahlecker collection.

Fig. S2 - Photomicrographs of thin sections from various localities. Sample numbers can be cross referenced on logs and discussed in text (Figs. 4 \& 6).

Fig. S3 - Compilation of field photographs taken during 2018 field season by authors. (A) Parasitic folding of Morro Fm. limestones in a subsurface quarry, Ribiera do Morro; (B) The Monte Carquiejo MC exposure logged in Fig. 7; (C) Wood debris found within the Carquiejo Fm., the white star in Fig. S2B shows location; (D-E) Ichnofacies on the base of a dolomitized limestone bed of the Morro Fm., Monte Branco, PI - Planolites, Th - Thalassinoides; (F) Ch - Chrondrites exposed on the base of a flaggy limestone of the upper transitional unit, Monte Carquiejo.

Fig. S4 - Calcareous nanno-fossil zonation for the Central Atlantic. NC Zones of Roth $(1978,1983)$, Subzones of Bralower (1987) and Bralower et. al. (1993). Hayesites irregularis and Flabellites oblongus are not recorded from the Morro Formation due to the poor preservation. In offshore wells (pers. obs) the FAD of Assipetra terebrodentarius youngii occurs immediately below the FAD of F.oblongus. In the 
Central Atlantic, the FAD of Hayesites irregularis overlaps with the LAD of Rucinolithus radiatus, a very similar form under the light microscope which makes the true FAD of $H$. irregularis difficult to identify. The LAD's of Zeugrhabdotus scutula and Conusphaera rothii approximate to the top Barremian in the current study. Ongoing studies will ascertain whether one or both forms range up into the earliest Aptian. Research in Morocco (Luber et. al., 2017 \& pers. obs) confirms LAD's below the base of the Deshayesites forbesi ammonite Zone.

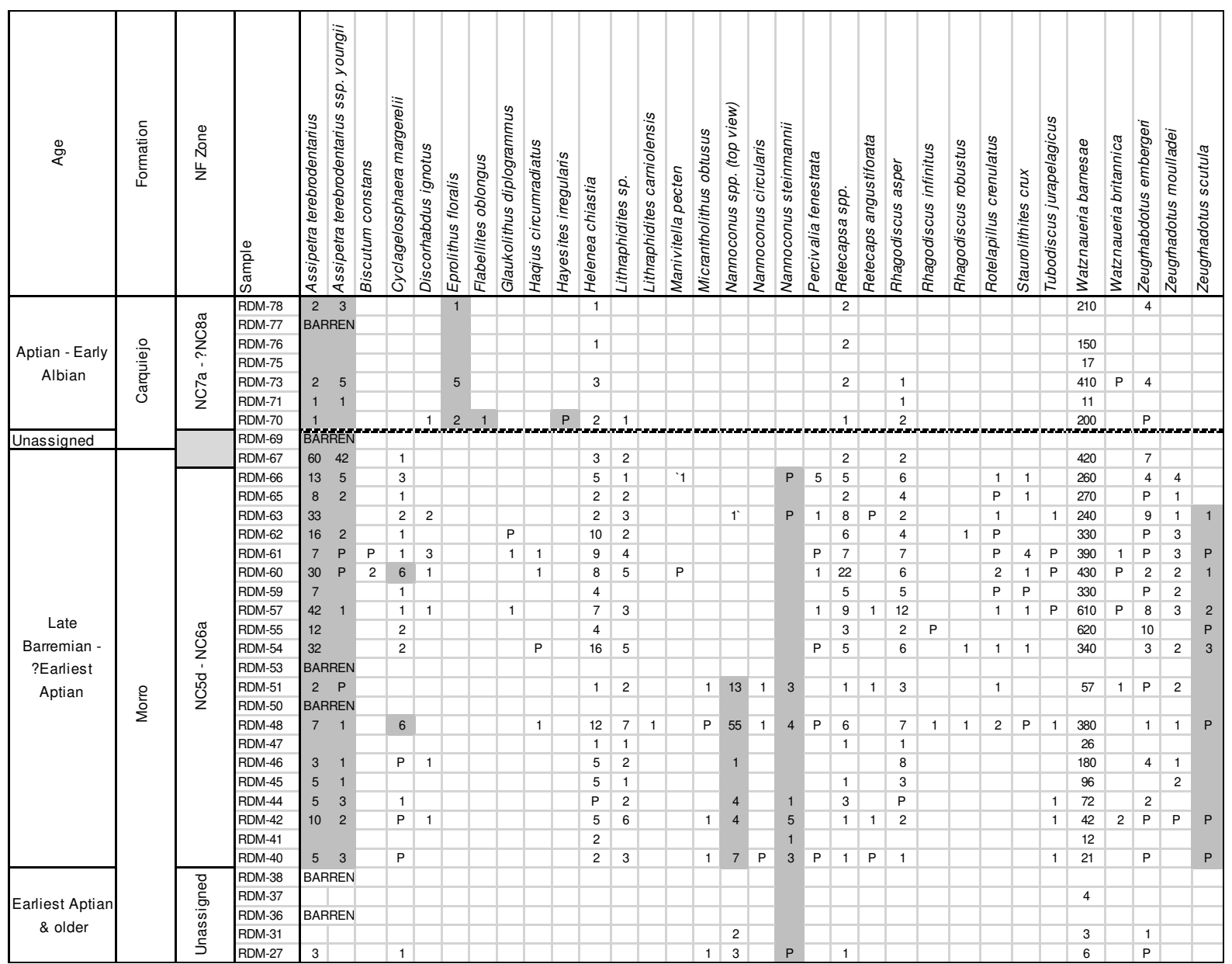




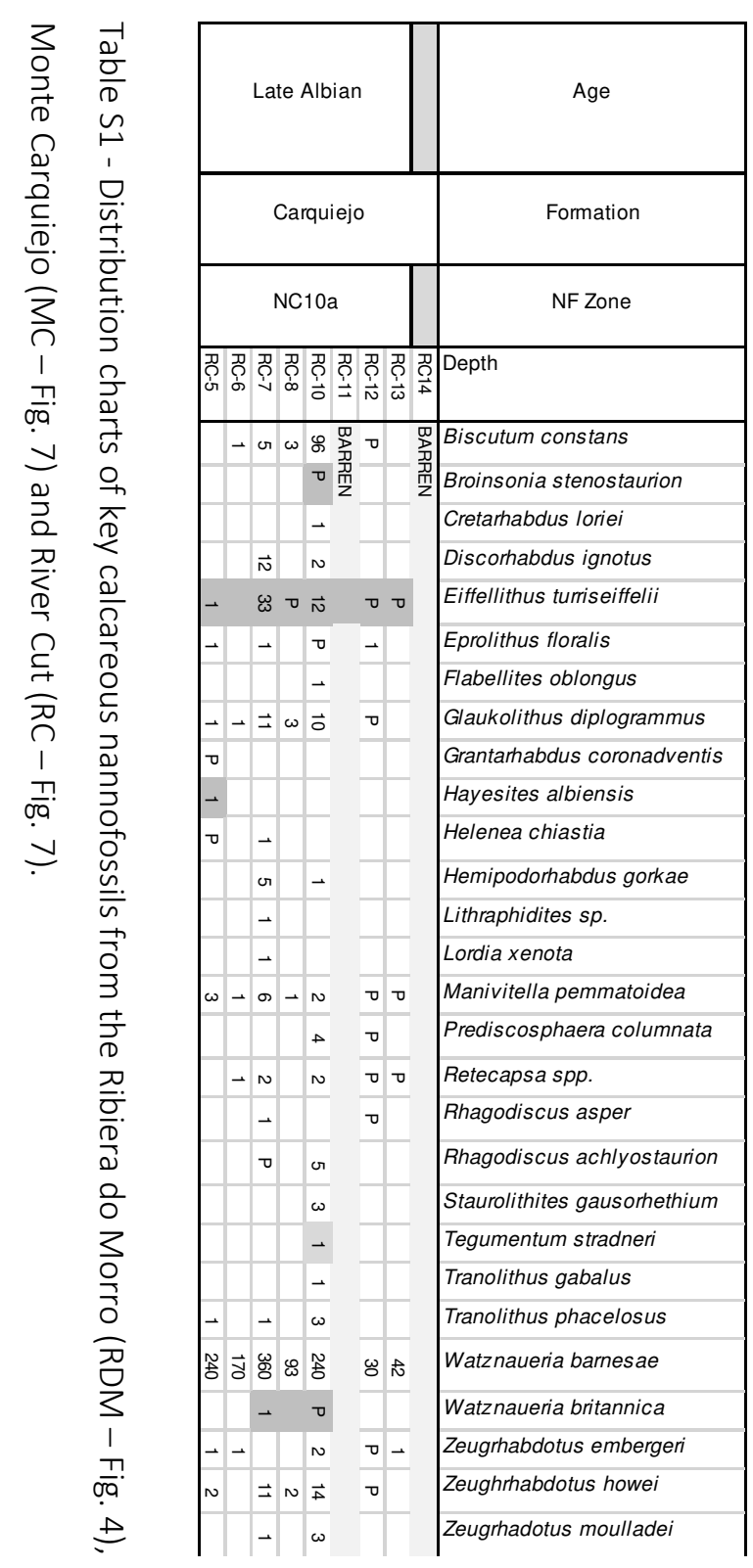

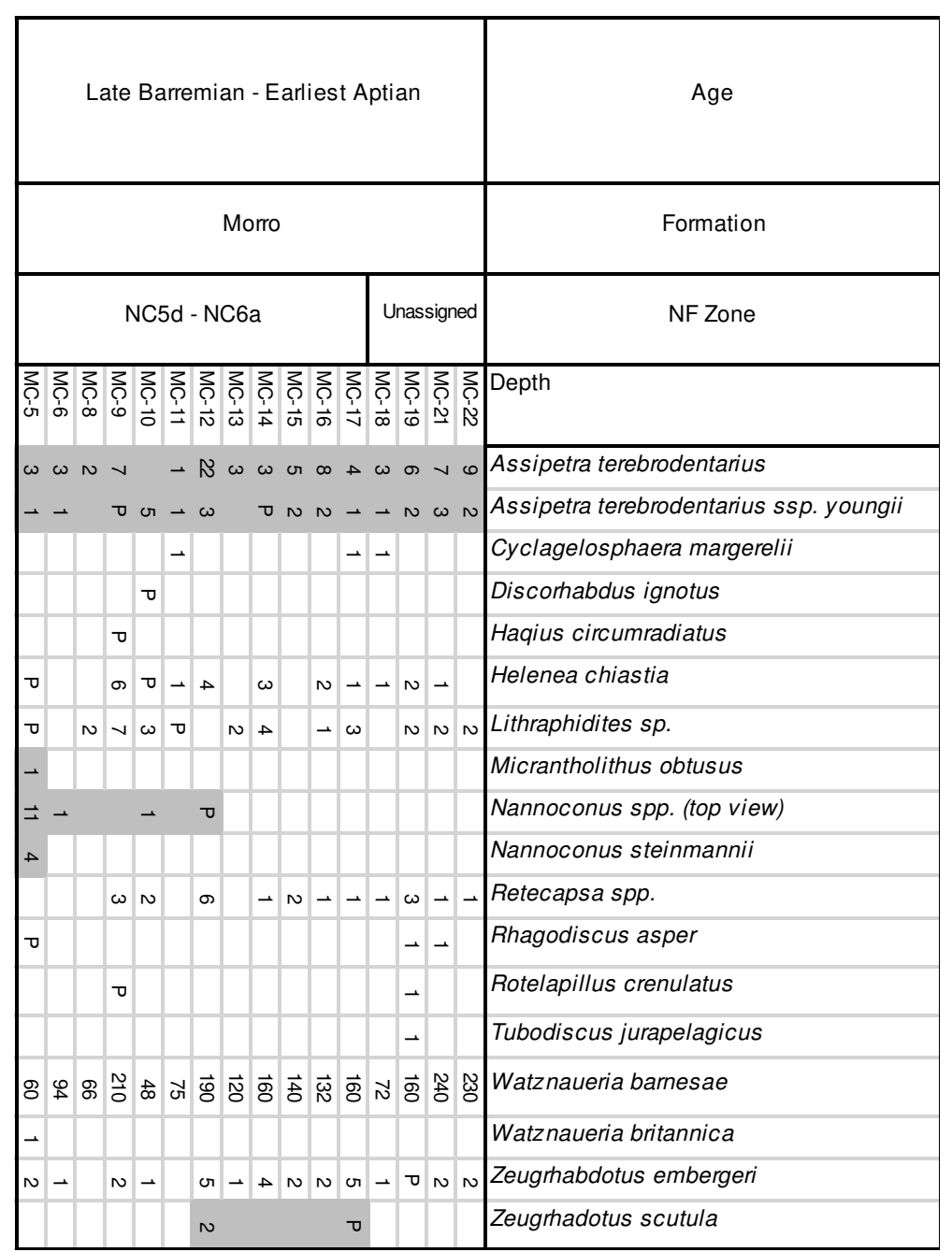

